\title{
SUID-AFRIKAANSE STAATS- en STAATSONDERSTEUNDE MILITÊRE GESKIEDSKRYWING (1924-1987)
}

\author{
Kol dr Jan Ploeger*
}

\begin{abstract}
INLEIDING
In sy eenvoudigste vorm is geskiedenis uitgedrukte herinneringe aan die verlede wat uit die menslike behoefte aan kennis van die oorsprong van dinge voortspruit. Hierdie uitgedrukte herinneringe is mondeling of skriftelik oorgedra. Reeds in die vyfde eeu voor Christus het die Griekse geskiedskrywer Thucydides (omstreeks $471 \vee \mathrm{Chr}$ - omstreeks $400 \vee \mathrm{Chr}$.), met betrekking tot sy weergawe van die Peloponesiese oor$\log (431 \vee \mathrm{Chr}-404$ v Chr.) doelbewus daarna gestrewe om - sover dit moontlik was - die gesketste gebeurtenisse waarheidsgetrou weer te gee.
\end{abstract}

In hierdie opsig het hierdie vroeë geskiedskrywer reeds met faktore soos die drang na objektiwiteit, sowel as met vermydelike en onvermydelike gevoelens van subjektiwiteite te kampe gekry.

Dié geskiedskrywers wat in die loop van die eeue eerlik teenoor hulle self, die beskikbare boustowwe en die toekomstige lesers sou staan het weliswaar steeds meer en meer besef dat dit onmoontlik was, en nog steeds is, om volslae objektief te wees. Onder dié besef moet daar ewenwel terselfdertyd voortdurend na gestrewe word om die hoogste graad van objektiwiteit en die waarheid te verwesenlik. ${ }^{1}$

Nie al die geskiedskrywers het hierdie goue reël altyd willens en wetens betrag nie en tot vandag toe kan daar voorbeelde in dié verband aangetref word.

In die loop van die eeue van geskiedenisbeoefening het die arbeidsveld van die navorsers en skrywers aanmerklik toegeneem en het daar 'n splitsing in verskeie onderafdelings plaasgevind. Voorbeelde hiervan is die politieke geskiedenis en -geskiedskrywing en die kultuurgeskiedenis en -geskiedskrywing.
Met verwysing na krygsgeskiedenis en krygsgeskiedeniskrywing kan opgemerk word dat in die verlede dié soort geskiedskrywing besonder geliefd was. ${ }^{2}$

In dié verband kan o.m. sir Edward Greasy se bekende studie The fifteen decisive battles of the world: From Marathon to Waterloo (London, 1887) en It Alfred von Müller se werk Der Krieg in Süd-Afrika 1899/1900 und seine Vorgeschichte (Berlin, 1900) as voorbeelde geneem word.

Sir Edward Creasy se destydse gesaghebbende studie het in 1851 verskyn en het tot 1887 tweeen-dertig drukke belewe. Hierdie skrywer het sy aandag uitsluitend op veldslae toegespits en in sy inleiding beklemtoon dat hy veral daarin belang gestel het om aan te toon

"how the chain of circumstances is to be linked together, that the smallest skirmish, or the slightest occurrence of any kind, that ever occurred, may be said to have been essential, in its actual termination to the whole order of subsequent events."

Lt von Müller het, op sy beurt, sy suiwer krygskundige beskrywings deur 'n beknopte staatkundige voorgeskiedenis van die Boererepublieke en gegewens met betrekking tot die strydkragte van die oorlogvoerendes laat voorafgaan om daarna sy volle aandag by die krygskundige gebeurtenisse te bepaal. ${ }^{4}$

In ons eie eeu het die beoefening van die gesketste krygsgeskiedenis sy gang gegaan, terwyl tewens aandag aan militêre geskiedenis en militêre geskiedskrywing gewy is en word.

Die volgende voorbeeld dui o.a. duidelik die verskille tussen die onderskeie werksterreine van die beoefenaars van die genoemde rigtings aan. 
In die voorwoord tot Je Maintiendrai A Concise history of the Dutch Army (The Hague, 1985), het die redaksie van hierdie studie o.m. verklaar:

"Although the authors of this survey of Dutch military history certainly do not ignore campaigns and battles, they make it clear that the description of an army in peacetime can not only be just as fascinating as what has been described as a drum-and-trumpet history, but certainly as instructive for the purpose of gaining an understanding of the course of historical events.

After all, once it is decided to continue a political struggle by military means, and the writers of battle histories proceed to sharpen their pencils, it will still take some considerable time before any army can tue raised from scratch."

\section{Aan hierdie uiteensetting is toegevoeg:}

"... the outcome of military confrontations usually depends more on the organisation, training, discipline and other facets of any army in peacetime than on the ingenious tactical instinct of a commander during the fighting itself." 6

Wanneer hierdie uiteensettings aanvaar word dan vloei hieruit voort dat militêre geskiedenis en -geskiedskrywing o.m. krygsgeskiedenis en -geskiedskrywing, eenheidsgeskiedenis en -geskiedskrywing e.d.m. omvat.

Binne die genoemde raamwerk val dan ook o.m. die volgende publikasies van een van SuidAfrika se baanbrekers-spesialiste op die gebied van sekere aspekte van die militêre geskiedenisbeoefening, dr H.H. Curson. Van sy hand het o.m. Colours and Honours in South Africa, 1783-1948 (1948); Regimental Devices in South Africa, 1783-1954 (1954); The S.A. Field Artillery in G.E. Africa and Palestine 1915-19 (1958, met brig F.B. Adler en maj A.E.Lorch), en The History of the Kimberley Regiment (Kimberley, 1963) die lig gesien.?

Van belang is ook die sienswyse wat die redakteurs Peter Warwick en prof dr S.B. Spies in die inleiding tot The South African War - The AngloBoer War 1899-1902 (London, 1980) verkondig het. Hulle het die aandag op die volgende aspekte gevestig:

"The book is organized in three parts: the advent of war, the war itself, and its aftermath. Each part is opened by a short narrative ac- count of the period under review. The chapters that follow deal with both the military and political history of the war, and above all, with its social history, an element that has often been neglected in the past." 8

\section{Doelstellings van vroeëre skrywers. Probleme}

In die lig van bostaande opmerkings is dit insiggewend om die aandag te vestig op die doelstellings van vroeëre skrywers oor die AngloBoereoorlog (1899-1902) en om tewens 'n oomblik stil te staan by hulle probleme.

Die Transvaalse amptelike oorlogsgeskiedskrywer N. Hofmeyr (1880-1932) wat voor die oorlog verantwoordelik vir geskiedenisonderrig aan die Pretoriase Staatsgymnasium was, het tydens die eerste maande van die oorlog met die skrywe van Zes maanden bij de Commando's begin en sy werk in April 1901 op Oudtshoorn voltooi. ${ }^{9}$

Watter doelstellings het hierdie eerste amptelike oorlogsgeskiedskrywer van die Zuid-Afrikaansche Republiek beoog? Sy werk was, volgens sy eie uitspraak, nie bedoel om die een of ander geliefkoosde stelling in verband met die militêre worsteling te verdedig of te weerlê nie. Ook het hy soveel moontlik vermy om kritiek uit te spreek en om die politieke terrein te betree. Hy wou vertel wat hy gesien, ondervind, gedink en gevoel het, terwyl hy aan die oorlog deelgeneem het. Hy het aan die kant van die republieke gestaan en geen aanspraak op

"schoon-klinkende, maar voor de meeste menschen onmogelijke onpartijdigheid"

gemaak nie. En aan hierdie bekentenis het Hofmeyr toegevoeg dat dit hom nie belet het om sy oë willens en wetens vir die goeie en edele van die teenparty te sluit nie.

Sy dryfveer in dié verband was dat die kloof tussen die twee Blanke rasse reeds so groot was en versoening en samewerking tussen hulle so noodsaaklik vir die stoflike, intellektuele, sedelike en godsdienstige welsyn van Suid-Afrika was, dat dit die plig van elke ware patriot was om te help om die bestaande kloof te demp en die gewenste harmonie te bevorder. ${ }^{10}$

Terwyl Hofmeyr sy standpunte onomwonde gestel het, het die Nederlandse skrywer W.F. Andriessen in die voorwoord tot sy Gedenkboek 
van den oorlog in Zuid-Afrika (Amsterdam-Kaapstad, 1904) o.m. 'n aantal vrae aan sy lesers voorgelê. Hy het o.m. gevra: Het die tyd reeds aangebreek om die oorlog in 'n onpartydige, historiese lig te stel? Is dit binne die bereik van die mens om uit alles, wat oor die stryd gesê en geskryf is, die waarheid te voorskyn te haal?" En dan was daar die fantasie en al die ander byvoegsels wat vir belangstellendes in Europa en Afrika gevaarlik was om op die regte spoor te bly. ${ }^{11}$

Maar Andriessen se allerbelangrikste vraag was of daar iemand in die wêreld sou wees wat oor voldoende en outentieke dokumente sou beskik om ' $n$ regverdige oordeel te kon vel. So 'n oordeel moes, aldus Andriessen, nie deur eensydige verheerliking of verguising vertroebel word nie.

Terwyl hy dus al hierdie vraagstukke en hinderpale raaksien en daarmee te kampe gehad het, het Andriessen andersyds tot die gevolgtrekking gekom dat hy feite kon versamel en ooreenkomstig in volgorde van tyd kon groepeer.

Dié feite kon dan sonder partydige beskouings of vooropgestelde menings aan belangstellendes voorgelê word. Op dié wyse sou groot gebeurtenisse as herinneringe bewaar en in die geheue van die opgroeiende geslag geplant word. Dit sou ook geld ten opsigte van versamelde voorbeelde van vaderlandsliefde, moed en doodsveragting, trou en pligsvervulling.

Andriessen was daarvan oortuig dat die vegtendes aan albei kante gemeen het dat hulle met 'n goeie doel tot die stryd toegetree het: Die Boer wou hom heeltemal van Britse inmenging losmaak, terwyl sy teenstanders opgevoed was in die trotse besef dat elke aanranding van die gesag van sy vorstehuis onduldbaar was. Dié skrywer het 'n eresaluut aan al die gevallenes gebring. ${ }^{12}$

Reeds voordat Andriessen sy denkbeelde aan sy lesers voorgelê het, het kapt dr W. Vallentin se tweedelige werk Der Burenkrieg die eerste lig in Leipzig aanskou. ${ }^{13}$

Hierdie skrywer, wat voor die oorlog ' $n$ tydlank in die Zuid-Afrikaansche Republiek vertoef het, het o.m. verklaar dat sy werk nie krygswetenskaplik van aard was nie. Dit was ook nie sy bedoeling om romanties gekleurde oorlogservarings of -belewenisse te publiseer nie. Sy doelstelling was om die Duitse volk 'n uitvoerige, verstaan- bare en onopgesmukte beskrywing van die groot vryheidstryd voor te lê.

Die tragiese afsluiting van dié stryd het in die hart van elke ernstige denkende mens 'n geval van verbittering laat posvat.

Verder het kapt dr Vallentin die wens uitgespreek dat sy werk 'n monument van die groot heldestryd sou wees wat die Nederduitse (-Nederlandse) stamverwante in Suid-Afrika vir vryheid en reg gevoer het. ${ }^{14}$

Nog vroeër, in 1902, het onder redaksie van L.S. Amery, die eerste deel van die toekomstige standaardwerk The Times History of the War in South Africa $1899-1900$ in Londen verskyn. ${ }^{15}$

In sy voorwoord het die redakteur die wenslikheid beklemtoon om eers die vooroorlogse politieke verwikkelinge te skets. Ofskoon dié deel sover moontlik uit 'n historiese standpunt behandel is, het Amery daaraan toegevoeg:

"though at so short an interval of time from the events themselves it is impossible altogether, on some occasions, to avoid a controversial tone.

Absolute impartially in dealing with so momentous and so recent a conflict of political principles and political ambitions is perhaps hardly attainable." 16

Verder het Amery onomwonde verklaar dat die eerste deel deur hom vanuit dié gesigshoek geskryf is en daaraan die gedagte verbind:

"that the essential right and justice of the controversy have been with his own country, and that the policy which has been pursued by the British Government has been both politically and morally, justifiable."17

Op 11 April 1902 het die tweede deel van die reeks die lig gesien en het Amery verduidelik dat hy eers ' $n$ beskrywing van die historiese ontwikkeling, die organisasie en die vernaamste kenmerke van die twee sterk uiteenlopende militêre stelsels moes geskryf het, alvorens hy met die verloop van die wapenstryd kon begin.

Amery het dit beklemtoon dat hy, in teenstelling met dr Conan Doyle, orals krities te werk gegaan en nie sy toevlug tot 'n skilderagtige, verbeeldingsryke styl geneem het nie. Volgens hom het hy daarna gestrewe om aan sy lesers die verhaal voor te lê van wat werklik gebeur het. Volgens sy mening was dié verhaal weliswaar kri- 


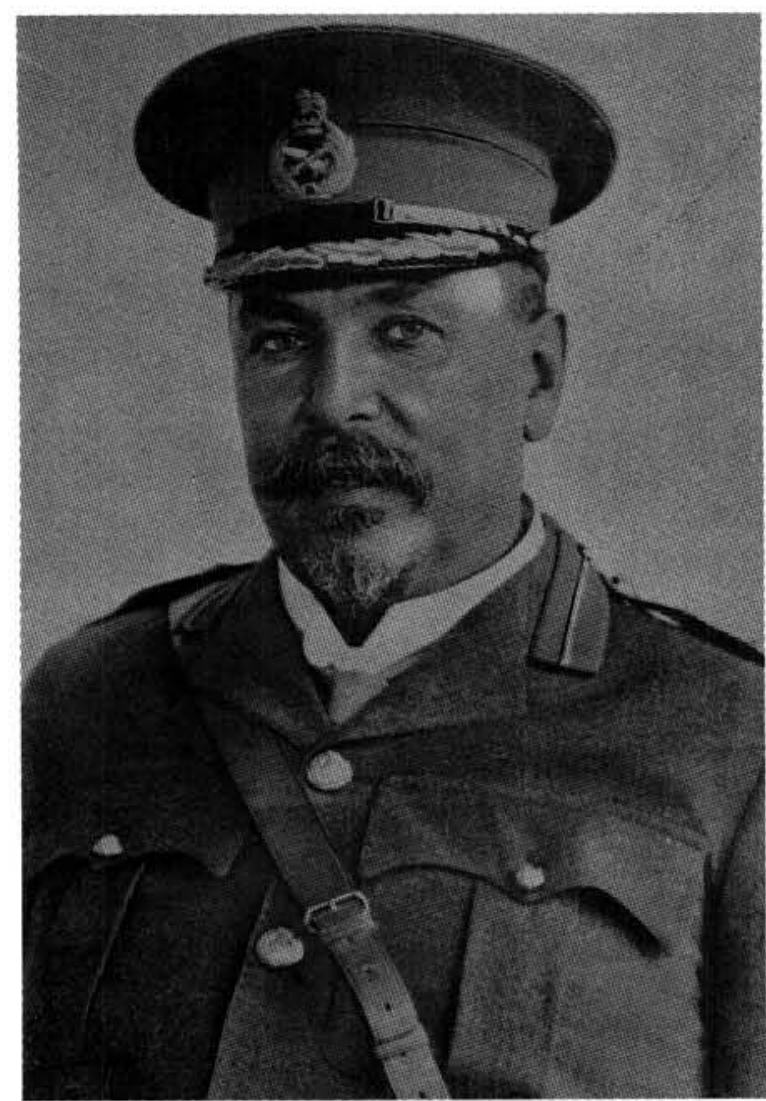

Generaal Louis Botha (1862-1919)

ties, maar terselfdertyd onpartydig en onbevooroordeeld. Hy het ook beklemtoon dat hy sy verhaal eers geskryf het nadat hy al die beskikbare boustowwe sorgvuldig bestudeer, gewik en geweeg het.

Ofskoon Amery o.m. heelwat gegewens uit verskillende oorde ontvang het, was hy bewus van die insluiting van verkeerde feite en foutiewe beoordelings. Hy het dié foute sowel as sy eie kritiek ten volle vir sy eie rekening geneem. ${ }^{18}$

Bostaande voorbeelde van skrywers wat hulle aandag op die Tweede Anglo-Boereoorlog (1899-1902) ten tye van of kort na dié ingrypende gebeurtenis toegespits het, is slegs ' $n$ uitermate beperkte steekproef. Dit geld ook ten opsigte van die uiteenlopende doelstelings wat hulle beoog het en ook met betrekking tot dié vraagstukke wat hulle in meerdere of mindere mate gekwel het.

Van 1906 dateer die eerste deel van Die Kämpfe der deutschen Truppen in Südwestafrika (Berlin, 1906), 'n publikasie wat in die krygsgeskiedkundige afdeling 1 van die Duitse generale staf ontstaan het. ${ }^{19}$ Die boustene van hierdie amptelike publikasie was van offisiële oorsprong. Voor- dat hierdie besonderhede in boekvorm verskyn het, is hulle as opstelle in die kwartaalblad Viertelheften für Truppenführung und Heereskunde gepubliseer.

Die bedoeling van die publisiteit, wat amptelik aan die Duitse veldtog teen die Hehero's gegee is, was om die Duitse volk in die geleentheid te stel om, in verstaanbare vorm, 'n aanskoulike beeld van die ontberings van die Duitse troepe te velde en hulle dapper optrede onder gevegstoestande te verkry. Dié prestasies het die dank van die vaderland verdien en die generale staf het dit as sy plig beskou om ' $n$ voorstelling van die stryd openbaar te maak. Om dié rede is daar tot dié stap oorgegaan ofskoon ' $n$ volledige, verantwoorde bronneuitgawe van die gebeurtenisse nog nie beskikbaar was nie.

Uit die aangehaalde besonderhede blyk dit duidelik dat dit die bedoeling was om die Duitse staatsburger ' $n$ beeld van die heldhaftige optrede en die ontberinge van die Duitse koloniale troepe in hulle stryd teen die Hehero's te gee om op dié wyse die bewoners in die moederland in staat te stel om hulle dank aan die genoemde troepe te betuig.

\section{Suid-Afrikaanse amptelike militêre ge- skiedskrywing na aanleiding van die Unie se deelname aan die Eerste Wêreldoorlog (1914-1918)}

Twee jaar na die totstandkoming van die Unie van Suid-Afrika (1910) het die jong staat, op grond van Wet nr 13, 1912 (die Verdedigingswet), oor sy eie verdedigingsorganisasie begin beskik. Kragtens hierdie wet is daar o.m. voorsiening vir 'n Staande Mag, 'n Kusgarnisoensmag, 'n Aktiewe Burgermag, verskillende reserwes en ' $n$ kadetorganisasie gemaak. ${ }^{20}$

In 1914 het die Eerste Wêreldoorlog uitgebreek en op 4 Augustus 1914 het Brittanje, en gevolglik die hele destydse Britse wêreldryk, waaronder die Unie van Suid-Afrika, tot die stryd toegetree.

Ses dae later het die Unie se kabinet, onder Eerste Minister genl Louis Botha (1862-1919), teenoor die Britse regering ingewillig om Duits Suidwes-Afrika aan te val. Die Volksraad het hierdie plan met 'n groot meerderheid (92-12) goedgekeur. Daar was verset onder dié Afrikaners wat onder leiding van leiers soos genl C.R. de Wet (1854-1922), afgetrede brig genl C.F. 
Beyers (1869-1914) e.a. die "gewapende protes" of "rebellie" geloods het.

In Februarie 1915 het hierdie gebeurtenis tot die verlede behoort en het die regering, nadat in September 1914 reeds Unietroepe by Port Nolloth en Lüderitzbaai aan land gegaan het, sy volle aandag aan die krygsverrigtings teen Duits Suidwes-Afrika begin wy. ${ }^{21}$

Nadat die veldtog ten einde geloop het, is Unietroepe na die westelike front (Frankryk) en DuitsOos-Afrika, waar hulle tot die einde van die vyandelikhede, in November 1918, in die veld was.

In totaal was ruim 140000 Blanke troepe, 200 verpleegsters, ruim 1900 lede van die Kleurlingeenheid en ongeveer 15000 lede van die Swart Arbeidskontingente aan en agter die onderskeie fronte bedrywig.

Ruim 120000 Blankes en Swartes in uniform was aan die tuisfront gestasioneer. ${ }^{22}$

Tydens die ampstydperk van kol Hendrik Mentz, DTD, as Minister van Verdediging het, in 1924 , die amptelike publikasie The Union of South Africa and The Great War 1914-1918 in 'n oplaag van 1000 eksemplare verskyn. Die drukker-verspreider van hierdie waardevolle werk van 230 bladsye, wat deur die Generale Staf, Verdedigingshoofkwartier, Pretoria, saamgestel was, was die Unie se staatsdrukkery en die prys per eksemplaar was op 15/6 vasgestel. Op 17 Oktober 1923 is die opdrag aan die Staatsdrukker verstrek om die manuskrip te druk. ${ }^{23}$

Sover vasgestel kon word was die skrywer van hierdie amptelike oorlogsgeskiedenis kapt (later maj) J.W.G. Leipoldt, 'n broer van die bekende digter-skrywer-medikus dr Christian Frederik Louis Leipoldt (1880-1947). Van hierdie offisier is o.m. bekend dat hy in 1913 ' $n$ personeellidinstrukteur van die Suid-Afrikaanse Militêre Skool op Bloemfontein was en tydens die veldtog in Duits Suidwes-Afrika, saam met kapt Nobbs, diens by die Unie se Militêre Inligtingsdiens gedoen het. ${ }^{24}$

In die voorwoord van dié publikasie is die beoogde doelstellings van die werk in die volgende woorde geskets:

"The main purpose kept in view has been to record the effort and achievement of South Africa as a whole, bearing in mind the old adage 'too many trees and one fails to see the wood'." 25

As gevolg van hierdie beleid is die toekomstige beskrywing van die prestasies van afsonderlike eenhede aan dié geskiedskrywers oorgelaat wat hulle op dié besondere gebied onderskei het.

Sonder probleme het, aldus die skrywer, die geskiedenis van Suid-Afrika se militêre deelname aan die Eerste Wêreldoorlog nie tot stand gekom nie. Een van dié probleme was die feit dat die oorlogspoging van die ander dominiums betreklik van dieselfde aard en gesentraliseer was, terwyl die Suid-Afrikaanse bedrywighede as gevolg van omstandighede - nie veel verband met mekaar gehad het nie. ${ }^{26}$

Daar was die krygsverrigtings in verband met die verowering van sekere doelwitte in Duits Suidwes-Afrika. As gevolg van die rebelllie in die Unie moes dié krygsverrigtings tydelik gestaak word. Die aandag is tydelik op die demping van die rebellie toegespits en daarna is die veldtog voortgesit. Daar was dus sprake van twee, selfs drie verwante ondernemings wat in ander opsigte aanmerklik verskil het.

Terwyl die rebellie-tydperk geskets is om sy omvang en sy verband met die militêre bedrywighede in Duits Suidwes-Afrika tot die leser te laat deurdring, het die eintlike veldtog in dié gebied in 1915 begin en geëindig.

Daarna is ' $n$ geslaagde poging in die Unie aangewend om ' $n$ infanteriebrigade onder brig-genl Henry Timson (Tim) Lukin (1860-1925) op die been te bring om Suid-Afrika aan die westelike front (Frankryk) te verteenwoordig.

Hierdie troepe wat in November 1915 in Engeland aangekom het en daarna vir frontdiens in Frankryk opgelei is, is in Desember van dieselfde jaar na Egipte gestuur om te help om die Senoessi naby die wesgrens van Egipte te verslaan. Nadat dié taak afgehandel is, is die brigade na Frankryk om sy plek in die geallieerde geledere in die omgewing van die Somme in te neem.

In die Official History is ruimskoots plek vir die beskrywing van die stryd by Delvillebos (d'Elvillebos), Warlencourt, Arras (Atrecht), die derde slag om leper en die Duitse offensief (November 1917-Maart 1918) sowel as ten opsigte van die verdere verloop van die gevegte in die laaste oorlogsjaar (1918) ingeruim. 


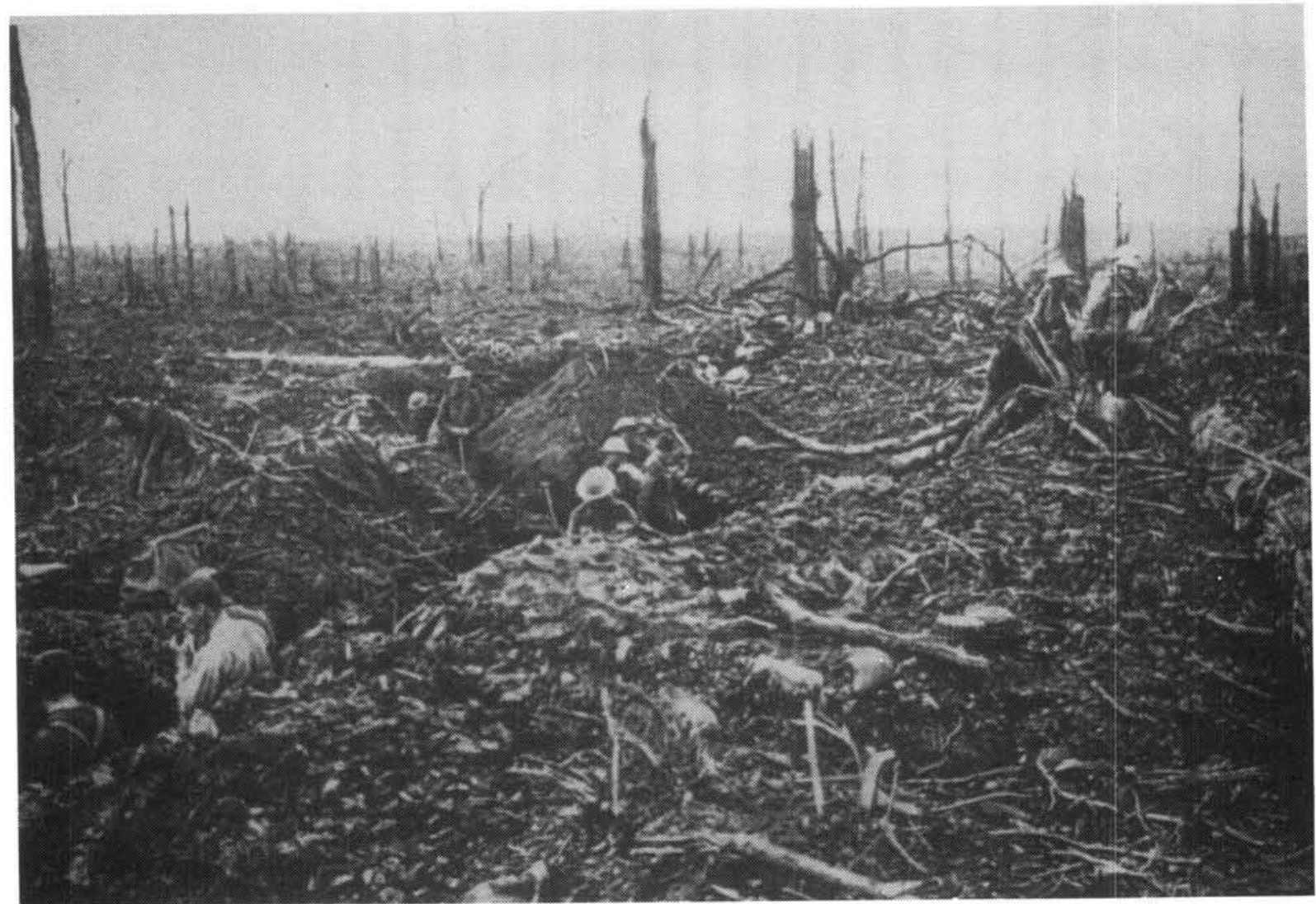

Delvillebos (SAW Argief 851000276)

Daar is voldoende aandag aan dié gedeelte van die veldtog in Duits Oos-Afrika gewy wat op die oorname van die opperbevel oor die geallieerde magte deur It-genl J.C. Smuts (18701950), in Februarie 1916, gevolg het. Soos bekend het genl Von Lettow Vorbeck en sy troepe die wapens op 25 November ${ }^{1} 918$ by Abercorn neergelê.

Aan die Suid-Afrikaanse deelname aan die militêre worsteling aan die onderskeie fronte en gedurende die genoemde tydperke is 182 bladsye van die Official History gewy. Die teks is met fotomateriaal en kaarte toegelig en die geheel vorm 'n betroubare, verstaanbare, taamlik oppervlakkige gids vir leke en vakkundiges wat meer kennis en insig oor die genoemde onderwerpe verlang.

Die genoemde besonderhede is met waardevolle gegewens oor die rol van die Suid-Afrikaanse Swaar Artillerie, die Suid-Afrikaanse Seinkompanie, die Suid-Afrikaanse Mediese Diens, die Spoorweg- en ander besondere vakkompanies, die Kaapse Kleurling-vervoerkompanies, die administrasie en 'n lys van Suid-Afrikaners, wat die Victoria Cross gedurende die oorlog verwerf het en 'n lys van noodlottige oorlogsongevalle afgesluit. ${ }^{27}$

Deur die Official History te publiseer is ' $\mathrm{n}$ besonder leesbare bron van militêr-historiese waarde die wêreld ingestuur. Dit was en is nog steeds 'n monument van blywende waarde ten opsigte van dié Suid-Afrikaners wat aan dié titaniese stryd deelgeneem het en is meer as 12000 gevalle (Blankes 8551, Kleurlinge - 709, Swartes 3192 ) die hoogste offer gebring het.

Reeds jare voordat hierdie amptelike publikasie die lig gesien het, het It genl J.C. Smuts beklemtoon dat verskeie van die minder belangrike strydtonele van die Eerste Wêreldoorlog die sorgvuldige aandag van militêre studente en navorsers vereis omdat die veldtogte, wat in sekere gebiede geloods was, onder ongewone toestande plaasgevind het.

Genl Louis Botha se veidtog in Duits SuidwesAfrika sou, volgens genl Smuts, altyd as ' $r$ model-veldtog in 'n woestyn bekend bly. Volgens sy mening het die vyand hom misgis deur te reken dat die bevoorradings- en vervoervraagstukke, o.m. van water, onoorkomelik vir 
die aanvaller sou wees. 'n Briljante en gewaagde strategie het ewenwel die teenoorgestelde bewys.

In 1916 was die veldtog in Duits-Oos-Afrika 'n treffende voorbeeld van 'n geslaagde militêre operasie in ' $n$ tropiese gebied. Binne tien maande is, ten spyte van ' $n$ vasberade vyand, natuurlike hindernisse en klimatologiese vraagstukke, 'n groot gebied beset. ${ }^{28}$

Hierdie uitsprake van genl Smuts regverdig o.i. die verskyning van die Official History in 1924 ten volle.

\section{Brig-genl J.J. Collyer se belangrike publikasies van 1937 en 1939}

In 1936 het brig-genl J.J. Collyer, CB, CMG, DSO, die voormalige Hoof van die Generale Staf van die Unieverdedigingsmag (UVM), tydens die veldtogte in Duits Suidwes- en Duits Oos-Afrika, die inleiding tot ' $n$ belangrike krygshistoriese studie afgerond. Dié studie het as The Campaign in German South West Africa 1914-1915 (Pretoria, 1937), as 'n amptelike publikasie verskyn.

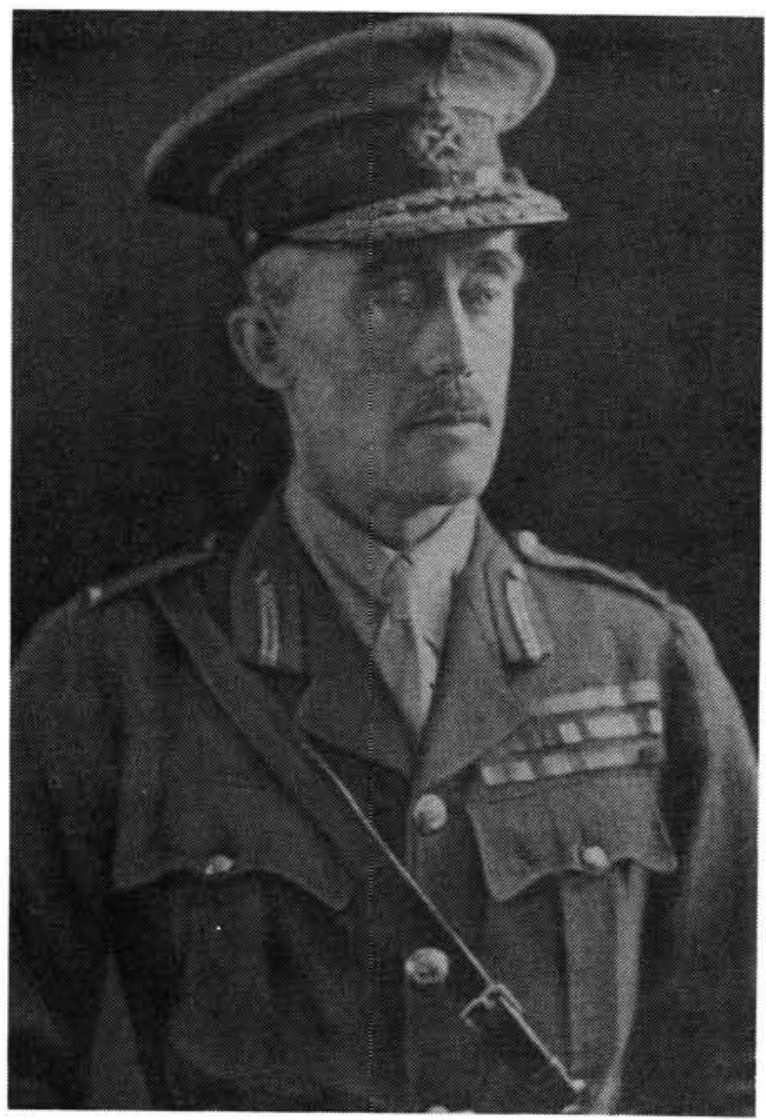

Brig-genl J.J. Collyer (SAW Argief 700004040)
In sy inleiding het die skrywer o.m. die volgende, waardevolle stelling beklemtoon:

"We learn wisdom from failure much more than from success. We often discover what will do by finding out what will not do; and probably he who never made a mistake never made a discovery." 29

Dit was na aanleiding van hierdie stelling dat brig-genl Collyer hom, in sy studie, beywer het om vroeër begane foute te beklemtoon. Op dié wyse wou hy voorkom dat die foute, onder soortgelyke omstandighede, in die toekoms weer begaan sou word.

Een van die foute van 1914 was, volgens hom, dat daar met uitsondering van 'n klein kader van beroepsoldate, deur die bank van lede van die Aktiewe Burgermag (ABM) gebruik gemaak is. Numeriek was die ABM te klein en moes daar tot 'n onvoorsiene en onvoorbereide uitbreiding oorgegaan word. So 'n toestand moes in die toekoms voorkom word deur die Staande Mag onmiddellik te vergroot. ${ }^{30}$

In hoofstuk XIV het die skrywer 'n groot aantal uiteenlopende wenke aan die hand gedoen om op dié wyse, in geval van 'n toekomstige oorlog, foute van die verlede te voorkom. In 1914 was daar o.m. ' $n$ talent aan opgeleide stafoffisiere en in die toekoms moes aanvoerders en manskappe, wat aan ' $n$ bewegingsoorlog sou deelneem, beter opgelei en afgerig word as in die verlede die geval was. ${ }^{31}$

Bogenoemde uitlatings van brig-genl Collyer is slegs 'n paar van dié wat hy in die genoemde publikasie genoem en bespreek het. Bygevolg kon hierdie gedeeltelike leerboek op meer volledigheid roem as die gedeelte wat in die Official History van 1924 aan dieselfde onderwerp gewy was.

'n Groot aantal uitstekende kaarte is aan die teks toegevoeg en op dié wyse het 'n hoogstaande, vakkundige studie van die eerste veldtog tot stand gekom wat selfstandig en op sy eie verantwoordelikheid deur die Unie van Suid-Afrika uitgevoer is. ${ }^{32}$ Die genoemde publikasie dra die kenmerke van 'n krygsgeskiedenis met 'n leende, moraliserende inslag.

In 1934 het, nou onder die titel Die veldtog in Duits Suidwes-Afrika 1914-1915, 'n vertaalde weergawe van die reeds genoemde studie van 1937 verskyn. ${ }^{33}$ 
In Mei van dieselfde jaar het brig-genl Collyer sy volgende werk, The South Africans with General Smuts in German East Africa 1916 (Pretoria, 1934) voltooi. Nog in dieselfde jaar het die vertaling, Die Suid-Afrikaners met Generaal Smuts in Duits Oos-Afrika (Pretoria, 1939) die lig gesien. Albei publikasies was amptelik en is, soos hulle voorgangers, deur die Staatsdrukker, Pretoria, gedruk. ${ }^{34}$

Soos in sy vorige studie het die skrywer ook in hierdie publikasie die nadruk op die waarde van ondervindings en die gedetailleerde studie daarvan deur militêre gelê. Uit 'n dergelike studie kon hulle, volgens sy mening, slegs voordeel trek. Op grond van hierdie oortuiging het hy dan ook, aan die begin van sy inleiding, die volgende uitspraak van De Peucker aangehaal:

"In vredestyd word die geskiedenis die ware middel om oorlog te bestudeer en om die vaste wette van die oorlogskuns te ondersteun." ${ }^{\text {35 }}$

Verder beklemtoon die skrywer o.m. in sy inleiding dat die troepe van die Unie in 1916 onskatbare ondervinding van oorlogvoering in uiters moeilike terrein opgedoen het. Tewens was hy van oordeel dat elke toekomstige oorlog in Afrika, ten suide van die ewenaar, belangriker sou wees aangesien dit die toneel vir die aanwending van Suid-Afrikaanse troepe in ' $n$ oorlog ter verdediging van die Unie kon word. ${ }^{36}$

Ook het hy die vermoede uitgespreek dat die Unieverdedigingsmag op die vasteland van Afrika sou veg en dat die moontlike oorlogstonele tussen die Kaap die Goeie Hoop en die ewenaar sou lê..$^{37}$

Aan hierdie inleiding, waarvan slegs 'n paar belangrike aspekte genoem is, het genl J.C. Smuts se voorwoord vooraf gegaan. Ook hy het die leersame aspekte van die outeur se werk beklemtoon en die werk sterk aanbeveel by dié studente wat belang in oorlogvoering onder tropiese toestande sou stel. Volgens sy mening was brig-genl Collyer se werk meer as ' $n$ militêrtegniese oorsig van die veldtog. Dit was, volgens sy siening, die verhewe verhaal van ' $n$ grootse menslike prestasie, 'n verband waarin 'n eensydige bekragting van die gebeure uit 'n geallieerde oogpunt geheel en al ontbreek het, maar waarin terselfdertyd die optrede van Belgiese troepe en die Suid-Afrikaanse burgerkrygsman, die eintlike held van die veldtog, lof toegeswaai is.
Aan hierdie uitspraak het genl Smuts die volgende gedagtes toegevoeg:

"Hulle het nog nouliks erkenning ontvang, want Oos-Afrika was mos sommer ' $n$ byaksie teen die ander veldtogte van die Groot Oorlog. Die eer is bestee aan hulle kamerade wat na die Westelike Front gegaan het.

Delvillebos, Marrièrebos en ander veldslae in Frankryk beklee die ereplekke op die oorlogsgeskiedrolle van Suid-Afrika.

Dit is verre van my om die helde van die Westelike Front hulle roem te misgun, want hulle roem is ook die roem van Suid-Afrika, maar eweneens moet ons nie vergeet dat daar ook heldedade in Oos-Afrika verrig is... Duisende lê daar in die verste noorde van ons trek deur Afrika. ${ }^{\text {"38 }}$

Brig-genl Collyer het veertien hoofstukke aan die agtergrond en die verloop van die veldtog in 1916 gewy en vervolgens aandag aan dié lesse gewy wat, volgens hom, uit sy militêre-historiese oorsig voortgespruit het. ${ }^{39}$ Onder dié lesse was o.m. die volgende: Die noodsaaklikheid om vir 'n oorlog of ' $n$ veldtog voor te berei, die aanwending van perderuiters in die tropiese bosveld, die administratiewe lesse (vervoer, kommissariaat, geneeskundige diens, verbindings en -lyne) en die taktiese lesse.

Die studie van die hand van genl Collyer het twee jaar voor It-kol Charles Hordern se eerste deel van die amptelike Military Operations East Africa (London, 1941) van die reeks History of the Great War verskyn. Dié reeks is op gesag van die Historical Section of the Committee of Imperial Defence saamgestel en die inhoud het op amptelike dokumente berus.

Die genoemde deel van hierdie Britse publikasiereeks bevat die verhaal van die krygsverrigtings in Duits Oos-Afrika gedurende die tydperk van Augustus 1914 tot September 1916. ${ }^{40}$

In die bibliografie kom sowel die publikasie The Union of South Africa and the Great War as briggenl Collyer se studie oor die veldtog in Duits Oos-Afrika onder genl Smuts voor. ${ }^{41}$

\section{Die amptelike publikasies van die afdeling Unie-Oorlogsgeskiedenis}

Tot vandag toe bestaan daar, sover die kennis van die skrywer strek, nog geen wetenskaplike verantwoorde uitvoerige beskrywing van hierdie afdeling nie. 
Voor die uitbreek van die Tweede Wêreldoorlog was maj Leipoldt en, later, brig-genl Collyer met die skryf van amptelike oorlogsgeskiedenisse belas.

'n Volwaardige afdeling, bekend as die afdeling Unie-Oorlogsgeskiedenis, het teen die einde van 1940 of aan die begin van 1941 ontstaan en aanvanklik onder die Departement van Verdediging en daarna onder die Kantoor van die Eerste Minister geressorteer. As hoof van hierdie afdeling het ' $n$ senior-lektor in die Departement Geskiedenis van die Universiteit van Pretoria, mnr (later: kol., prof. dr.) J.A.I. Agar-Hamilton, opgetree. Aanvanklik het hy oorlogsverlof geniet om in 1946 uit die diens van die universiteit te tree. Hy het die genoemde afdeling tot 1961 gelei. $^{42}$

Onder sy bekwame leiding en met behulp van ' $n$ aantal uitstekende medewerkers het kol AgarHamilton 'n belangrike versameling amptelike en nie-amptelike argiefmateriaal aangelê en 'n drietal werke gepubliseer wat 'n nuwe rigting aan die Suid-Afrikaanse militêre en -krygsgeskiedenis gegee het. In 'n drietal publikasies het die genoemde beleid duidelik sigbaar geword. In verskeie opsigte staan die inhoud aanmerklik hoër as dié van die reeds genoemde studies oor die Suid-Afrikaanse deelname aan die Eerste Wêreldoorlog.

Bekend is dat, op 'n onbekende tydstip, 'n adviserende raad onder prof dr H.B. Thom, destyds hoogleraar in geskiedenis aan die Universiteit van Stellenbosch, aan hoofredakteur kol AgarHamilton toegevoeg is. Op 7 November 1943 het die Eerste Minister (genl J.C. Smuts) besluit om ' $n$ raadgewende komitee aan die genoemde raad toe te voeg. ${ }^{43}$

In 1952 het die adviserende raad i.v.m. die oorlogsgeskiedenis uit prof dr H.B. Thom (voorsitter), It-kol G. Graham Botha, mnr D. de Waal Meyer, prof I.S. Fourie, mnr G.W.R. de Mare, prof A.F. Hattersley en dr C. Beyers bestaan. ${ }^{44}$ $\mathrm{Na}$ die aftrede van dr Beyers as hoofargivaris van die Unie is sy plek deur sy opvolger, dr A. Kieser, ingeneem. ${ }^{45}$

Hoofredakteur kol Agar-Hamilton is agtereenvolgens deur assistent-redakteurs dr Eric Axelson, maj L.C.F. Turner (militêr) en kapt J.E. Betzler bygestaan. Verder het kmr H.R. Gordon-Cumming, OBE, RN, verantwoordelikheid vir ' $n$ deel van die inhoud van War in the Southern Oceans 1939-45 (Cape Town, London, N. York, 1961) aanvaar. Op 'n sekere tydstip was kapt J.E.
Betzler as argivaris-vertaler werksaam, terwyl hy in 1961 die pos van assistent-redakteur beklee het. Kartograaf P. Alton het waardevolle werk verrig en dié groepie is deur ' $n$ aantal assistentnavorsers, tiksters e.d.m. bygestaan. ${ }^{46}$

In die destydse Unie het die hoofredakteur oor onbeperkte toegang tot amptelike oorlogsdokumente beskik en reeds in 1942 is met ' $n$ ondersoek na die val van Tobroek begin.

Met betrekking tot die eerste werk, Crisis in the Desert May-July-1942, in 1952, is o.m. hulp deur lede van die Staande Mag verleen wat oor kennis van dié onderwerp beskik het.

In Engeland het o.m. die hoof van die historiese afdeling van die Britse Kabinet se Kantoor, sowel as 'n groot aantal Britse offisiere hulle hulpvaardigheid betoon. Soortgelyke bystand is uit Nieu-Seeland, die VSA, Italië, Pakistan en Duitsland ontvang. Behalwe dat daar dankbaar van hierdie ongepubliseerde bronne gebruik is, is baie publikasies uit of kort na die oorlogsjare met vrug geraadpleeg. In dié opsig is die biografiese lys (pp. 345-346) besonder insiggewend.

Uit hierdie en ander nie-spesifiek genoemde boustowwe is deur die hoofredakteur en assistent-redakteur maj L.C.F. Turner Crisis in the Desert May-July 1941 opgestel. Die navorsingswerk in verband met die val van Tobroek het na die Duitse aanslag op die Gazalalinie, veldmaarskalk Erwin Rommel se daaropvolgende offensief teen Egipte, sy oorwinning by Mersa Matroe en die einde van sy opmars by El Alamein gelei. ${ }^{47}$

Dit is slegs ' $n$ klein gedeelte van ' $n$ verkenningsen navorsingsterrein wat, in die loop van die tyd onder die aandag van die outeurs en hulle medewerkers gekom het. En as gevolg van al die verskillende aspekte is die genoemde publikasie in drie dele, t.w. The Gazala Line, Tobruk en Alamein ingedeel.

Dit is, op grond van die verstrekte agtergrond, duidelik dat - met die publikasies van die genoemde afdeling - die geskiedenis van die oorlogsgeskiedskrywing in ons land 'n nuwe ontwikkelingsfase tegemoet gegaan het.

In verband met die totstandkoming van The Sidi Rezeg Battles 1941, in 1957, het die reeds genoemde skrywers, teen die groot woestynoffensief van November 1941 as agtergrond, die op- 
trede van 1 SA Infanteriedivisie nagegaan en die verwerking van al die beskikbare gegewens in twintig hoofstukke (pp 1-467) voltooi en 'n nawoord daaraan toegevoeg.

Soos sy voorganger is ook hierdie gesaghebbende studie ruimskoots van fotografiese materiaal, kaarte, nuttige bylaes, 'n waardevolle bronnelys en 'n register voorsien.

O.m. kon amptelike dokumente van die Agste Leër sowel as van die Panzergruppe Afrika geraadpleeg en verwerk word. Die outeurs het tewens alles in hulle vermoë gedoen om brandende vraagstukke met betrekking tot die Crusaderveldslae te probeer ontrafel en oplos. ${ }^{48}$

In die voorwoord tot War in the Southern Oceans $1939-45$ is o.m. vermeld dat die eerste oorsig van die bedrywighede van die Suid-Afrikaanse Vloot deur kmdt H.R. Gordon-Cumming OBE, $\mathrm{RN}$, opgestel is. Daarna het maj Turner 'n grootskaalse strategiese studie van die vlootbedrywighede in die omgewing van die Kaap die Goeie Hoop en in die suidelike oseane onderneem. Verder is gegewens van dr Eric Axelson oor die SALM met vrug geraadpleeg. Kapt Betzler en kmdt Gordon-Cuming, OBE, RN, het navorsingswerk by die Britse abmiraliteit gaan onderneem. In 1954 het kapt Betzler waardevolle aanvoorwerk in Duitsland verrig.

Die skrywers het hulle verhaal met die kruistog van die Admiral Graf Spee en die ondergang van die Watussi (1939) begin om daarna die agtereenvolgende Duitse strooptogte in die twee oseane, albei belangrike skeepvaartroetes, na te gaan. Daarna het vyandelike duikbootoptrede gevolg totdat, in 1944, die gety in die nadeel van die aanvallers begin verloop. Onder meer is bylaes in verband met Duitse duikbote, sowel as oor Suid-Afrikaanse vaartuie en bemannings wat aan die Britse Vloot geleen is, in die uiters waardevolle werk opgeneem wat in 1961 verskyn het. $^{49}$

'n Terugblik in verband met die werksaamhede van die Afdeling Unie-Oorlogsgeskiedenis lewer, selfs met inagneming van leemtes in ons kennis, o.m. die volgende feite op.

Behalwe dat die drie genoemde gesaghebbende publikasies tot stand gekom het, is ' $n$ groot aantal voorlopige geskiedenisse, op grond van beskikbare gegewens, opgestel. Hierdie kosbare gegewens word tot 1961 slegs gedeeltelik gepubliseer. Dan was daar waardevolle fo- tomateriaal, tydskrifte, militêr-historiese brosjures, koerantknipsels, fotostate, amptelike- en nie-amptelike publikasies, oorlogskaarte e.d.m. in die afdeling se argief aanwesig.

'n Vierde, ongenoemde publikasie was byna voltooi toe, nadat die werksaamhede van die adviserende komitee op 31 Julie 1959 ten einde geloop het, die sluiting van die afdeling in 1961 gevolg het.

$\mathrm{Na}$ die ontbinding van die afdeling is die aanwesige militêre argiewe na die destydse Krygshistoriese afdeling van die Suid-Afrikaanse Weermag oorgeplaas. Die ander argiewe is aanvanklik na die Sentrale Argiefbewaarplek. Pretoria, gestuur en later na die Suid-Afrikaanse Weermag oorgeplaas. ${ }^{50}$

Deur beoefenaars van die militêre - sowel as die krygsgeskiedenis, belangstellende oudgediendes en ander wat die aandeel van SuidAfrika in die Tweede Wêreldoorlog (1939-1945) graag volledig geboekstaaf wou sien - is die sluiting van die Afdeling Unie-Oorlogsgeskiedenis betreur. Dit was ook die geval met hulle wat die noodsaaklikheid beklemtoon het dat die wêreld beslis moet kennis neem van wat SuidAfrika in dié opsig vermag het. 'n Ander gedagte is reeds in 1941 deur Carel Birkby in die inleiding tot sy nie-amptelike Springbok Victory uitgespreek:

"... I hope you will like this book, for it tells the extraordinary story of an extraordinary war, the like of which may never be known again in the world's history, because the methods of warfare have changed so greatly" ${ }^{51}$

En in 1965 kon ' $n$ ander bekende skrywer oor die Suid-Afrikaners se militêre aandeel in die Tweede Wêreldoorlog, It kol Harry Klein, in sy bekende Springboks in Armour. The South African Armoured Cars in World War II (Cape Town, Johannesburg) o.m. getuig:

"A story of high endeavour and great military achievement lies behind the short-lived history of the South African Tank Corps. Born of humble beginnings early in 1940, the infant Corps wrote a brilliant chapter in South Africa's annals of war before being absorbed by the South African Armoured Corps in 1943".

Van It genl George E. Brink, CB, CBE, DSO, is met verwysing na dieselfde eenheid - die volgende loftuiting afkomstig: 
"As one who had part in the birth, organization and training of the South African Tank Corps and subsequently had several of the Units in my command in East Africa, Abyssinia and North Africa I shall always look back with pride and affection on the achievements of that grand body of men who made up the personnel of that splended Corps." ${ }^{152}$

Kon dit toegelaat word dat die ongepubliseerde gedeeltes van die verhaal van die optrede van hierdie en ander Suid-Afrikaanse stryders op land, op see en in die lug in argiewe sou bly rus? En kon hulle vergeet word wat die hoogste offer gebring het?

Een van dié Suid-Afrikaners wat in dié trant geredeneer het, was It genl George E. Brink.

\section{Die optrede en verdienstes van It genl George Edwin Brink (1889-1971)}

In sy voorwoord tot kmdt (later kol) Neil Orpen se standaardwerk East African and Abyssinian Campaigns (Cape Town, Johannesburg, 1968) het die voorsitter van die destydse Advieskomitee insake Oorlogsgeskiedskrywing, mnr C.G. Kerr, onder meer vermeld op watter wyse die afdeling Unie-Oorlogsgeskiedenis in Junie 1961 sy deure gesluit het nadat die reeds genoemde Advieskomitee reeds in Julie 1959 ontbind is.

Lt genl Brink het, in sy hoedanigheid as voorsitter van die Raad van Korps-, Regiments- en verwante Verenigings, ook bekend as die Council of Corps, Regimental and Kindred Associations, gevra dat die besluit van 1961 hersien kon word. Aan hom is meegedeel dat die argiewe van die voormalige afdeling na die Unie-argief oorgeplaas en vir navorsing toeganklik sou wees. Terwyl die vroeëre hoofredakteur van die vroeëre afdeling nog ' $n$ viertal boeke beplan het wat die geskiedenis van die Suid-Afrikaanse Lugmag (SALM), die veldtog in Abessinië, die veldtog in Italië en die ontbrekende deel van die krygsverrigtings in Noord-Afrika sou behels, het genl Brink in 1961 die standpunt beklemtoon dat - tensy vroegtydig fondse ingesamel sou word dié genoemde werke nooit sou verskyn nie.

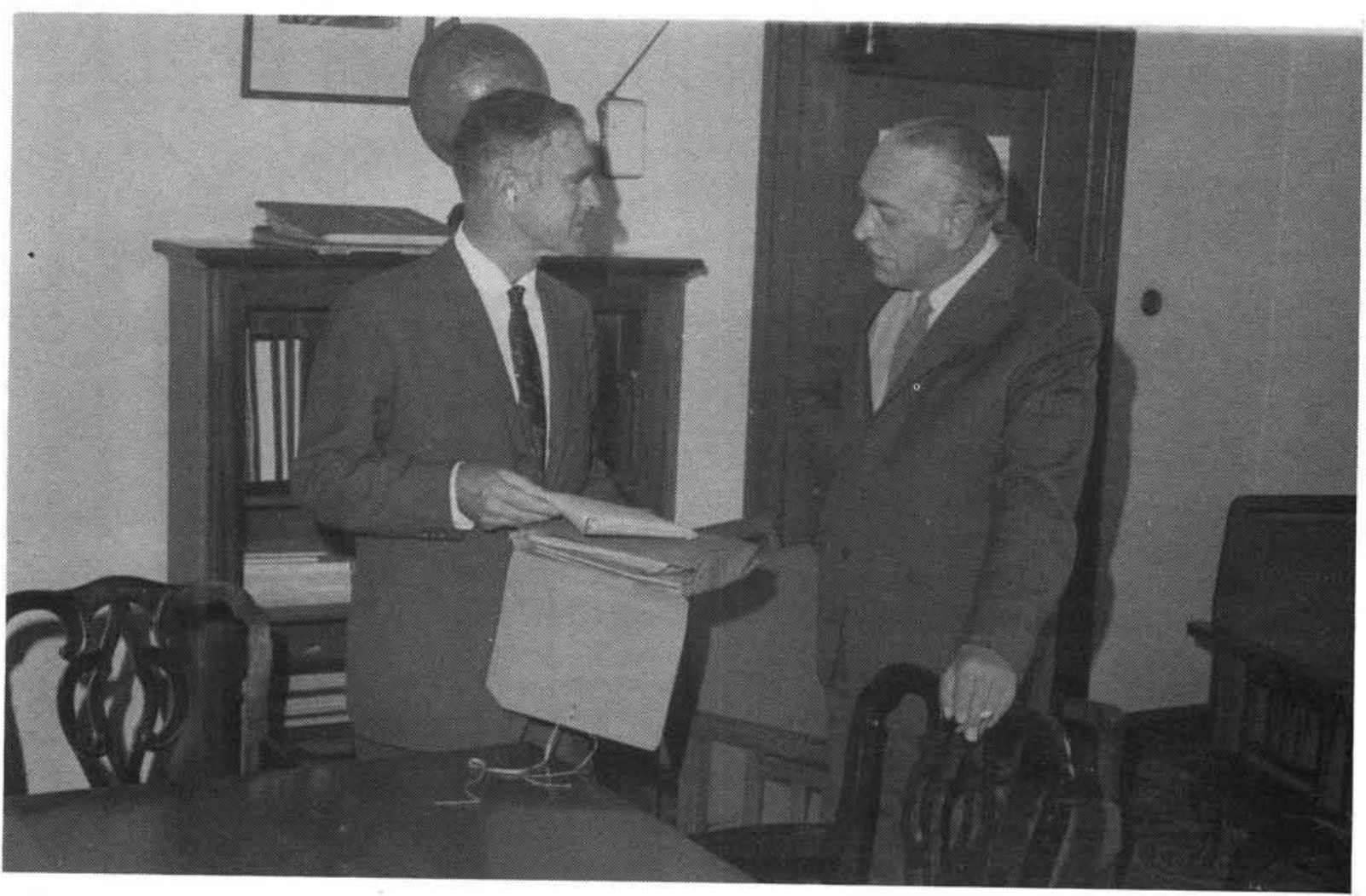

Oorhandiging van dokumente van genl Theron aan genl G.H.F. Markgraaff, S.M., deur kmdt Neil Orpen, J.C.D. Kmdt (later kol) Neil Orpen, J.C.D., M.A. (Cantab) was 'n voormalige joernalis wat een van die leidende Suid-Afrikaanse oorlogsgeskiedskrywers sou word. Baie beskou hom as die doyen van die Suid-Afrikaanse militere historici (SAW Argief 7000003760). 
Om dit te probeer voorkom is ' $\mathrm{n}$ beroep op al die organisasies van oud-gediendes gedoen en R10000 ingesamel. Daarna het, op versoek van genl Brink, kol D. Ollemans die Advieskomitee insake Oorlogsgeskiedskrywing in die lewe geroep en voor sy afsterwe is nog geldelike bydraes van 'n drietal koerantgroepe ontvang.

Vervolgens het die komitee kmdt (later kol) N.N.D. Orpen, Orde van die Ster van Suid-Afrika (Nie-Militêr) Klas 4 (Offisier), JCD, aangestel om die geskiedenis van die Oos-Afrikaanse veldtog na te gaan en op skrif te stel.

Kmdt Neil Orpen, M.A. (Cantab) was 'n voormalige joernalis wat een van die leidende Suid-Afrikaanse oorlogsgeskiedskrywers sou word. Gedurende die Tweede Wêreldoorlog het hy met 2 Ligte Lugafweerregiment in Egipte en Cyrenaica diens gedoen en is by Tobroek gevange geneem. $\mathrm{Na}$ die oorlog het hy sy joernalistieke loopbaan, en sy militêre bedrwighede as bevelvoerder van die Cape Field Artillery, voortgesit en militêre geskiedenis geskryf. In die toekoms sou hy naam as ' $n$ voortreflike militêre historikus verwerf.

Terselfdertyd is aan mnr James Ambrose Brown opgedra om die verhaal van die Suid-Afrikaanse Lugmag tydens die Tweede Wêreldoorlog te skryf.

Op dié stadium het die advieskomitee besef dat die benodigde fondse, in die lig van die beoogde publikasies, ontoereikend sou wees. Bygevolg is ' $n$ beroep op handels- en nywerheidskringe gedoen. Hierdie beroep is heelhartig deur die invloedryke sir Keith Acutt ondersteun, en aangemoedig.

Terwyl die afdeling Unie-Oorlogsgeskiedenis in 1961 gesluit is, het Eerste Minister dr H.F. Verwoerd die wenk aan genl Brink gegee om 'n versoek aan die destydse Departement van Onderwys, Kuns en Wetenskap te rig om subsidie te mag ontvang. Dié versoek is toegestaan en prof dr D.W. Krüger was die eerste verteenwoordiger van die Nasionale Raad vir Maatskaplike Navorsing (Pretoria) op die reeds genoemde advieskomitee. Genl R.C. Hiemstra, Kommandantgeneraal, Suid-Afrikaanse Weermag, het die grootse onderneming ook aangemoedig en die skrywer van hierdie bydrae en kapt $E$. Jonker as die eerste verteenwoordigers van die SAW op die genoemde advieskomitee benoem. Die skrywer van hierdie bydrae het, tot kort na sy aftrede in 1973, o.m. verantwoordelikheid ten opsigte

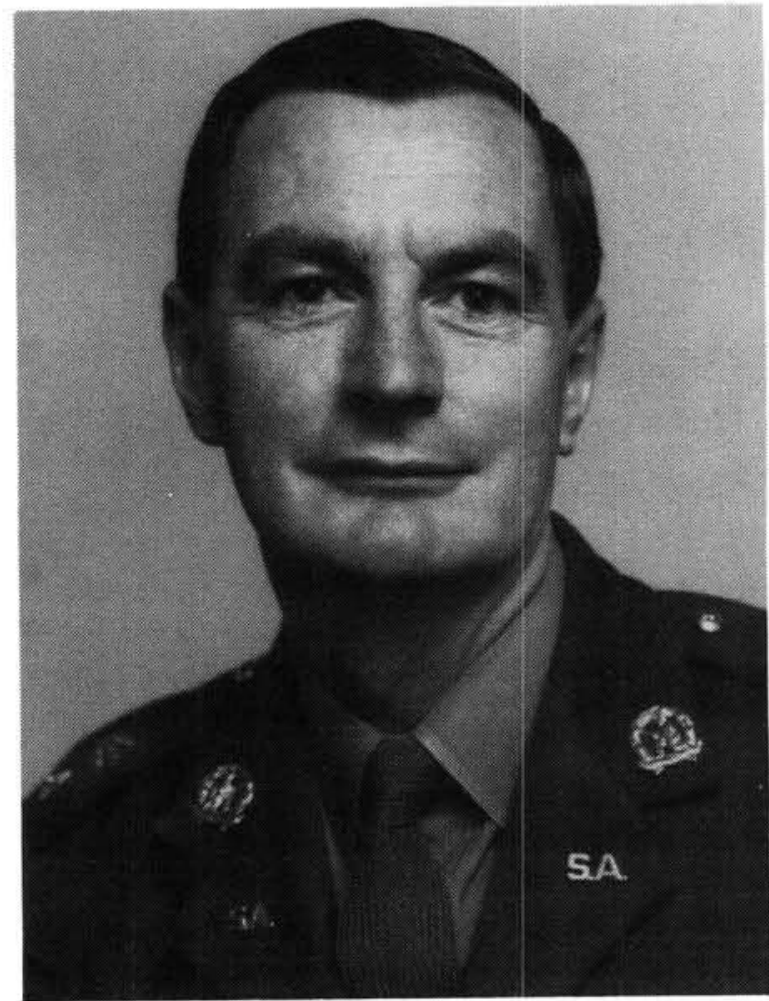

Kmdt G.R. Duxbury (Foto: Suid-Afrikaanse Museum van Militêre Geskiedenis)

van die vergelyking van die manuskripte met dié argiewe gedra wat destyds deur die MilitêrHistoriese en Argivale Dienste (MHAD) van die SAW beheer is. ${ }^{53}$

In 1968 het die Advieskomitee bestaan uit: Mnr C.G. Kerr (voorsitter), It genl G.E. Brink, CB, CBE, DSO, brig J.T. Durrant, CB, DFC, kol W.P.F. McLaren, OBE; kol J. Williams, DSO, DFC, It kol K.T. Gilson, DSO, kmdt G.R. Duxbury, maj R.D. Meeser, MC, maj R.J. Southey, ED, mnre L.H. Walton en L.E.A. Slater, kapt K. Hunter, kmdt (later kol) (dr) Jan Ploeger en kapt E. Jonker (namens die MHAD, SAW), prof dr D.W. Krüger (namens die Nasionale Raad vir Maatskaplike Navorsing) en maj E.B. Edmeades (ere-sekretaris) $^{54}$

In die tweede deel van die reeks, wat in 1970 verskyn het, het voorsitter C.G. Kerr o.m. getuig:

"Agter dit alles staan die onuitblusbare energie en wysheid van die 81 jarige genl George Brink, wie se dryfkrag en geesdrif van belang van hierdie onderneming van onverminderde krag bly". ${ }^{55}$

Almal wat die voorreg gehad het om in een of ander hoedanigheid onder It genl Brink te werk sal hierdie aanhaling ten volle beaam sonder om 


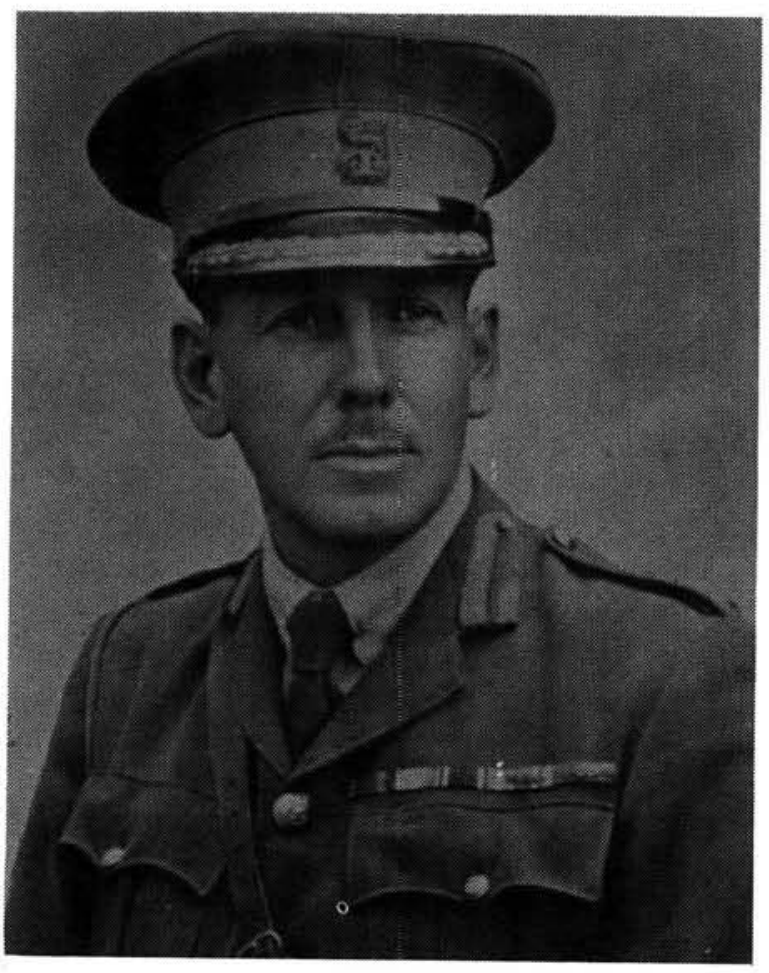

Lt genl George Edwin Brink (SAW Argief 700002108)

die werk van al die ander, wat tot die verwesenliking van ' $n$ groot doelstelling bygedra het, te onderskat.

George Edwin Brink (Jagersfontein, 27 September 1889 - Port Shepstone, 30 April 1971) was 'n gebore Vrystater en die seun van landdros J.G. Brink. Tydens 'n deel van die Tweede AngloBoereoorlog (1899-1902) was hy o.m. op Jagersfontein en Bloemfontein woonagtig. Daarna is die vader as superintendent van die Burgerkamp op Vredefortweg (vandag: Greenlands) benoem en het die gesin dertien maande in die kamp deurgebring. In 1907 het die jong George sy gevorderde studie aan die bekende Greykollege (Bloemfontein) afgerond en vervolgens uiteenlopende werksaamhede op Bloemfontein, Kroonstad en Johannesburg verrig (1908-1913).

In Augustus 1913 het hy as tydelike klerk tot die Departement van Verdediging, met Oos-Londen as standplaas, toegetree. In Junie 1914 is hy as distrikstafklerk op Graaff Reinet aangestel om in Oktober van dieselfde jaar sy kommissierang te ontvang. Hy is aan die staf van die bevelvoerder van die Suidelike Mag (Upington) vir diens tydens die Rebellie en die veldtog in Duits Suidwes-Afrika toegevoeg.

Stafkaptein G.E. Brink neem o.m. aan die krygsverrigtings teen genl J.C.G. Kemp deel, verrig daarna ' $n$ kort rukkie diens op die staf van kol (later It genl sir Jacobus) van Deventer en vertrek v oeg in 1915 na Namakwaland om as stafkaptcin 10 Berede Brigade (kol B. Bouwer) diens te doen. In dié hoedanigheid neem hy, later as brigade-majoor, onder It genl J.C. Smuts aan die inval in Duits Suidwes-Afrika deel om na sy terugkeer in die Unie 'n kort tydjie op die staf van die Direkteur van Oorlogswerwing diens te doen.

Op 12 Apri 1916 volg sy benoeming as stafkaptein onder b:ig genl Hermanus (Manie) Nicolaas Wilhelmus Botha (1877-1950) van 1 SA Berede Brigade. Hy neem aan die veldtog in Duits OosAfrika onder It genl J.C. Smuts deel, word op 9 Augustus 1916 tot brigade-majoor bevorder en keer na aanleiding van 'n malaria-aanval met drie maande siekteverlof na die Unie terug. Op 19 Mei 1917 is hy op It genl Van Deventer se staf aangestel om in September 1918 na Pretoria teruggeroep te word om die demobilisasie van die Unieverdedigingsmag (UVM) voor te berei.

In 1919 is hy na die Imperial Staff College om Camberley, Engeland, waar hy met welslae 'n kursus gevolg het. Na sy terugkeer in 1921 volg sy aanstelling as adjudant en offisier-instrukteur (administrasie) aan die SA Militêre Kollege (Robertshoogte). Daar het hy dertien jaar diens gedoen om op 1 Mei 1933 sy aanstelling as bevelvoerder van troepe, Robertshoogte, te ontvang. Terselfdertyd was hy kommandant van die SA Militêre Kollege en stigter-bevelhebber van die Spesiale Diensbataljon (SDB).

Op 18 Desember 1933 is kol Brink na Kaapstad $\mathrm{om}$, in sy reeds genoemde rang, die bevel oor die Kaapse kommandement tot 1 Februarie 1937 oor te neem. Daarna is hy deur die destydse Minister van Verdediging, adv O. Pirow, na Brittanje, Duitsland, Italië en Denemarke gestuur om die organisasie, toerusting en militêre opleidingsmetodes, en in Denemarke liggaamlike opleidingsbeginsels, te bestudeer. In Duitsland en Frankryk het hy militêre oefeninge bygewoon.

Na sy terugkeer na die Unie is kol Brink op 1 November 1937 as Direkteur van Leërorganisasie en -opleiding van die UVM benoem. Op 15 Junie 1938 het sy benoeming as Adjunk-Hoof van die Generale Staf, met die rang van brigadegeneraal, gevolg.

In 1937, 1938 en 1939 was hy in bevel van 'n reeks taktiese oefeninge wat in Noord-Transvaal 
gehou is. Ten tyde van die uitbreek van die Tweede Wêreldoorlog (1939) was genl Brink verantwoordelik vir dié daarstelling van 'n militêre opleidingsorganisasie en - sentrums oor die lengte en breedte van die Unie en vir die uitbreiding van die SA Militêre Kollege.

Tot Oktober 1939 het hy die opleiding van die veldleër gelei om op 21 Oktober 1940 na Kenia te vertrek om, in die rang van generaal-majoor, 1 SA Infanteriedivisie aan te voer.

In opdrag van It genl sir Alan Cunningham het genl maj Brink Suid-Abessinië binnegedring om die platorand tot Mojale skoon te maak, 'n opstand teen die Italianers onder die plaaslike Abessiniërs aan te wakker en om ongeveer sewe Italiaanse divisies in Suid-en Midde-Abessinië vas te keer. Daarna is genl Brink met sy divisie na Mersa Matruh om in November 1941 die regterflank van genl Auchinleck se invalsmag in Libië te dek. $\mathrm{Na}$ ' $n$ suksesvolle opmars tot Benghazi is die geallieerdes in Januarie 1942 genoodsaak om terug te val. Genl Brink is opgedra om die Gazalalinie te beset ten einde veldmaarskalk Rommel se opmars te probeer stuit. Aanvanklik het die verbondenes daarin geslaag om die vyand se eerste poging op 8 Februarie 1942 af te slaan.

As gevolg van ' $n$ rugbesering is genl Brink kort daarna na die Unie terug geroep, ongeskik vir velddiens verklaar en op 1 Julie 1942 het hy die bevel oor die pasgestigte binnelandse gebiedkommandement, met Johannesburg as hoofkwartier, aanvaar.

In September 1944 is aan hom opgedra om die Unie se veldleër se mobilisasie en die lede se toekomstige hervestiging in die burgerlike samelewing voor te berei. Met genl Brink as direkteurgeneraal van demobilisasie is 395 komitees, voorbereidingsdepots, edm in die lewe geroep.

Op 31 Maart 1948 het genl Brink se dienstermyn verstryk. Hy het reeds op 26 September 1946 uit die Staande Mag getree en is met ingang van dieselfde datum met die rang van luitenant-generaal na die Reserwe van Offisiere, Generale Staf (Afdeling 1), oorgeplaas. Hy het sy werk as direkteur-generaal van demobilisasie met welslae uitgevoer en van 1 April 1948 tot 31 Maart 1950 sy land as voorsitter van die immigrantekeurraad gedien.

Genl Brink is, nadat hy sy glansryke militêre loopbaan afgesluit het, kort daarna as verteenwoordiger van die Departement van Binnelandse Sake op die Raad van Kuratore van die destydse Suid-Afrikaanse Oorlogsmuseum, Johannesburg, benoem. Van 28 Oktober 1957 het hy, tot sy vertrek na St Michaels on Sea, op 31 Oktober 1969, as voorsitter van die genoemde raad opgetree. Tewens was hy voorsitter van die Suid-Afrikaanse Raad van Oudgediendes, die British Forces Committee van die Suid-Afrikaanse Raad van Oorlogsgrafte en die Adviserende Raad in sake Unie-Oorlogsgeskiedenis en ' $n$ lid van die Advieskomitee in verband met Oorlogsgeskiedskrywing.

In die Krygshistoriese Tydskrif (deel 2, $\mathrm{nr} 1$, Junie 1971) is van die ontslapende getuig:

"Ex-servicemen have indeed lost a true friend and South Africa a most distinguished son."

Lt genl G.E. Brink het die tydelike met die ewige verwissel voordat kmdt N.N.D. Orpen se War in the Desert gepubliseer is. Kenmerkend was ewenwel voorsitter C.G. Kerr se opmerking in die voorwoord tot die derde deel van die reeks:

"General George Brink died before publication of this book, but he guided the author throughout." ${ }^{56}$

Die South African Forces World War II - reeks is een van dié uitstaande bewyse van It genl Brink se deursettingsvermoë en sy onbeskryflike liefde en agting vir die verdedigingsorganisasie van Suid-Afrika en hulle, wat binne die raamwerk van die organisasie, as landverdedigers opgelei was en -in oorlogstyd- bereid was om die hoogste offer te bring. Dat sowel sy vaderland as buitelandse moondhede sy militêre kundigheid en leierskap na waarde geskat het, bewys die groot aantal onderskeidings en toekennings, waarvan die volgende genoem word: Die Croix de Guerre (avec palms), 1918; die Distinguished Service Order (DSO), 1918; Die Order of the Bath (CB), 1914; die Order of the British Empire (OBE), 1942. Verder was genl Brink die trotse draer van die Order of St John of Jerusalem (ridder-kommandeur) en was hy Groot Offisier in die Orde van Oranje-Nassau (met de zwaarden), 1943. Tewens was hy in besit van die 1914-1915 Star, die British War Medal, die Victory Medal, die 1939-1945 Star, die Africa Star, die War Medal (1939-1945) en die Africa Service Medal, sowel as die King George V Silver Jubilee Medal (1935) en die King George VI Coronation Medal $(1937) .{ }^{57}$ 


\section{Besonderhede met betrekking tot die South African Forces World War II-reeks}

Inleidend is reeds een en ander met betrekking tot die inisiatief van It genl George E. Brink, die ontstaan en doelstellings van die Advieskomitee en die keuse van 'n tweetal skrywers van die beoogde reeks vermeld. Van kmdt Orpen se dienste wou die komitee ten opsigte van die landoorlog gebruik maak terwyl mnr James Ambrose Brown die optrede van die Suid-Afrikaanse Lugmag (SALM) sou uitwerk. Die eersgenoemde het o.m. reeds in 1967 bekendheid deur sy studie Prince Alfred's Guard 1856-1966 (Cape Town, 1967) verwerf."

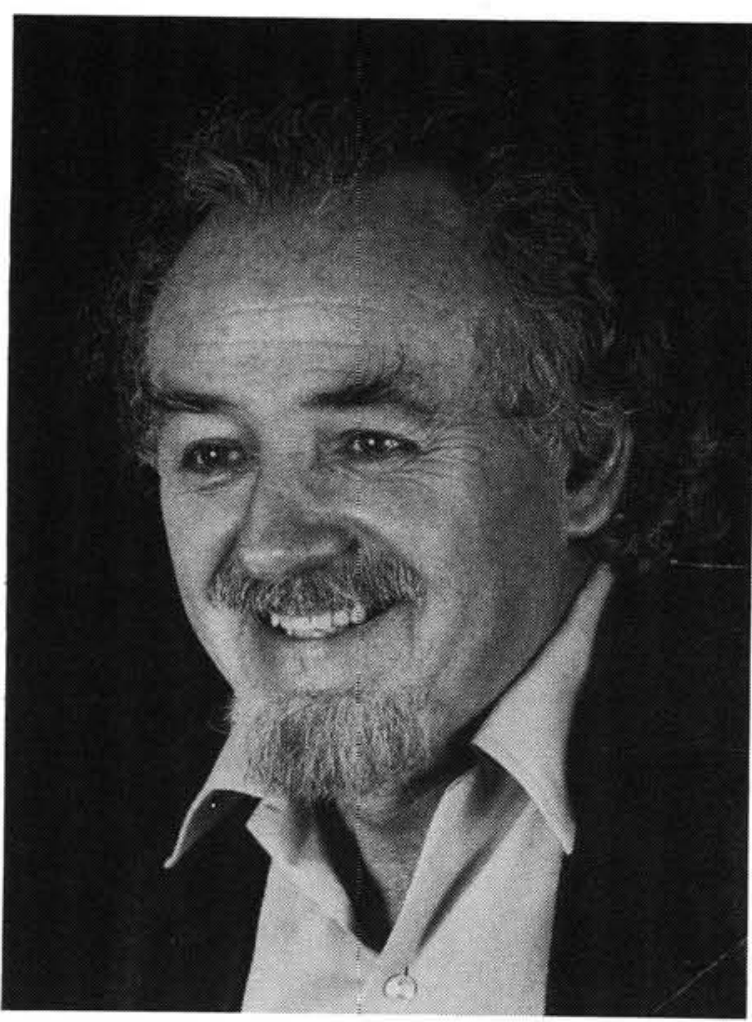

Outeur James Ambrose Brown. (Foto: The Star)

Vandag word hy as een van die toonaangewende militêre historici van sy tyd in ons land beskou ${ }^{59} \mathrm{Mnr}$ James Ambrose Brown het o.m. bekendheid as ' $n$ vooraanstaande prosaskrywer verwerf. In 1971 het sy roman The Return, in gedramatiseerde, fiktiewe verhaal teen die agtergrond van gebeurtenisse in Suidwes-Afrika tussen 1904 en 1922, 'n prys van R2 000 i. die Engelse afdeling van 'n literêre prysvraag verwerf wat tydens die destydse Republiekfees gehou is. ${ }^{60}$

Mnr Brown was verantwoordelik vir die totstandkoming van deel 2 van die reeks (tw A Gathering of Eagles, 1970) en deel 4 (tw Eagles Strike). In hierdie twee dele is die aandeel van die SALM in die krygsverrigtings in Oos-Afrika (1940-1941), Egipte, Cyrenaica, Libië, Tunisië, Tripolitanië en Madagaskar (1941-1943) beskryf.

Met betrekking tot die beskrywing van die optrede van die SALM in Europa was die Advieskomitee gelukkig om die medewerking van It genl H.J. Martin BA, SM, CBE, DFC, Belgiese Croix Militaire (I) verkry. Lt genl Martin was, tot sy aftrede in 1968, Hoof van die Verdedigingstaf, SA Weermag; en het tydens die Noord-Afrikaanse veldtog 12 Eskader SALM en later 3 Vleuel SALM aangevoer. Na die oorlog was hy o.m. Kwartiermeester-generaal, SA Weermag en Hoof van die Lugmag, SA Weermag. Hy het oor 'n uitgebreide kennis van die dokumentasie van die Weermagargief beskik en sy vooroorlogse loopbaan as ' $n$ joernalis begin.

Terwyl kmt Orpen deel 5 van die reeks tw Victory in Italy geskryf het, het hy en It genl H.J. Martin saamgewerk om die volgende dele van die reeks saam te stel, tw deel 6 - Eagles Victorious (1977) en deel 7 - South Africa at War (1979). Vervolgens het, van die hand van hierdie outeurs, dele 1 en 11, tw Salute to the Sappers $(1981,1982)$ verskyn. Dié twee dele is deur die Sappers Association (Johannesburg) gepubliseer.

Tussen 1968 en 1982 het dus die volgende dele van die South African Forces World War II-reeks die lig gesien:

1968 - deel 1 Kmdt Neil Orpen, East African and Abyssinian Campaigns (Cape Town, Johannesburg), pp 390 (met foto's, kaarte edm). Hierdie werk behels die gesaghebbende verhaal van SuidAfrika se militêre bydrae tot die oorwinning oor die Italianers in Oos-Afrika (1941) en die krygsverrigtings van die Oos-Afrikamag in samewerking met troepe van die Soedan in Eritrea.

1970 - deel 2 James A. Brown, A Gathering of Eagles. The campaigns of the South African Air Force in Italian East Africa June 1940-November 1941 with an introduction 1912-1939 (Cape Town, Johannesburg, London), pp 342. Hierdie werk bevat o.m. 'n 
volledig gedokumenteerde weergawe van die lugoorlog in Kenia, Somaliland, Abessinië, Die Soedan en Eritrea.

1971 - deel 3 Kmdt Neil Orpen, War in the Desert (Cape Town, Johannesburg), pp. 538, bevat dié gedeeltes van die krygsverrigtings in Noord-Afrika wat in die verlede nie deur die skrywers van die Afdeling Unie-Oorlogsgeskiedenis behandel is nie, terwyl andersins die hele militêre worsteling in die woestyngebied bedryf is. Daar is veral aandag aan dié rol gewy wat deur 1 en 2 Suid-Afrikaanse Divisies gespeel is.

1974-deel 4 James Armbrose Brown, Eagles Strike. The campaigns of the South African Air Force in Egypt, Cyrenaica, Libya, Tunisia, Tripolitania and Madagascar 1941-1943 (Cape Town, Johannesburg, London), pp 448. Die vanselfsprekende titel gee ' $n$ deeglike insig in die inhoud van hierdie werk wat, soos sy voorgangers, ruimskoots van kaarte en foto's voorsien is. In die volgende dele het It genl H.J. Martin die bogenoemde skrywer met betrekking tot die lugoorlog vervang.

1975 - deel 5 Kmdt Neil Orpen, Victory in Italy (Cape Town, Johannesburg), pp 340. Dit is die boeiende verhaal van die optrede van 6 Suid-Afrikaanse Pantserdivisie van die slag van Cassino tot die ineenstorting van die Duitse magte in Italië. Aandag is ook aan die bedrywighede van ander Suid-Afrikaanse eenhede vanaf die landing in Sicilië gewy.

1977 - deel 6 Lt genl H.J. Martin en kol Neil Orpen, Eagles Victorious. The Operation of the South African Forces over the Mediterranean and Europe, in Italy. The Balkans and the Aegean, and from Gibraltar and West Africa. (Cape Town, Johannesburg. London), pp 494. Hierdie werk gee die leser 'n duidelike beeld van die rol wat Suid-Afrikaners, in vergelyking met hulle bondgenote van Amerika, Brittanje en ander lande - in die stryd gespeel het om die oormag in die lug te verskyn en te behou.

1979-deel 7 Lt genl H.J. Martin en kol Neil Orpen, South Africa at War Military and Industrial Organisation and Operations in connections with the conduct of the War, 1939-1945 (Cape Town, Johannesburg, London), pp 405. Terwyl 'n vroeëre SuidAfrika se binnelandse oorlogspoging beskryf is, is in bogenoemde werk baanbrekerswerk verrig. In dié waardevolle studie, waarin o.m. ook die rol van genl sir Pierre van Ryneveld en sy verhouding tot veldmaarskalk J.C. Smuts bespreek is, is tewens aandag aan oorlogsproduksie en oorlogsuitgawes, die stryd teen die duikbote en die na-oorlogse tydperk gewy.

In sy voorwoord tot hierdie deel het voorsitter C.G. Kerr o.m. vermeld dat dié deel die reeks sou afsluit, maar dat die advieskomitee genader was om die geskiedenis van die Suid-Afrikaanse Genie, die "Sappers", te boek te stel. Aan dié versoek is voldoen en kol Neil Orpen en It genl H.J. Martin het aan die werk gespring. Die resultaat was

1981 - deel 8/1 Neil Orpen en It genl H.J. Martin, Salute the Sappers. The formation of the South African Engineers Corps and its operations in East Africa and the Middle East to the Battle of Alamein (Cape Town), pp 507. 'n Jaar later het die tweede deel van hierdie werk onder die volgende titel gevolg:

1982 - deel 8/2 Neil Orpen en It genl H.J. Martin, Salute the Sappers. The operations of the South African Engineer Corps in the North African and Italian theaters of war from the Battle of El Alamein to the end of World War II, with a brief description of subsequent 
developments (Cape Town), pp 424.

Met die verskyning van hierdie werke is ' $n$ monumentale reeks afgesluit en is vakkundiges en belangstellende leke in ons land en elders in staat gestel om 'n gesaghebbende reeks oor die Suid-Afrikaanse aandeel in die Tweede Wêreldoorlog tot ons eer ter hand te neem en met vrug te raadpleeg.

\section{Amptelike publikasies van die huidige Militêre Informasieburo, SAW en sy voorgangers (1968-1987)}

In die voorafgaande gedeelte is o.m. melding van die daadwerklike steun gemaak wat deur die Suid-Afrikaanse Weermag met betrekking tot die South African Forces World War II - reeks verleen is. Hierdie hulp en steun het o.m. daaruit bestaan dat die erkende navorsers-skrywers van die reeks die argiewe van die SA Weermag, met inbegrip van die skriftelike nalatenskap van die afdeling Unie-Oorlogsgeskiedenis, kon raadpleeg. Verder is deur personeel van die MilitêrHistoriese en Argivale Dienste (MHAD) en sy opvolgers o.m. kontrolewerksaamhede verrig.

Kortliks kan hier vermeld word dat die stigting van 'n volwaardige militêre SAW-argief op 14 Junie 1950 met die aanstelling van die Stafoffisier Argief verwesenlik is. In Januarie 1953 het die argief begin funksioneer en op 16 Augustus 1967 het die destydse Minister van Verdediging sy goedkeuring aan ' $n$ afsonderlike argiefbewaarplek verleen. Op dieselfde dag is die benaming Kryghistoriese Afdeling deur dié van SAWArgief vervang.

Die militêr-historiese en argivale bedrywighede van die voormalige Krygshistoriese Afdeling is tot 29 Junie 1968 deur die SAW-Argief beheer. Op dieselfde datum is dié Argief, saam met die ander bestaande funksies van die eertydse Krygshistoriese Afdeling onder die omvattende benaming Militêr-Historiese en Argivale Dienste gestig.

Oktober 1972 het die benaming Sentrale Dokumentasiediens gebring wat op 1 Februarie 1975 'n volwaardige direktoraat geword het. ${ }^{61}$

In 1969 het die MHAD oor 'n afsonderlike publikasie begin beskik wat onder die benaming Militaria tot vandag toe bestaan. ${ }^{62}$
Tewens is, behalwe hierdie militêr-historiese tydskrif ook ' $n$ reeks afsonderlike, soortgelyke publikasies uitgegee. In dié reeks het tot 1987 die volgende dele verskyn:

1. Komdt J. Ploeger Die Fortifikasie van Pretoria. Fort Klapperkop - Gister en Vandag/ The Fortification of Pretoria. Fort Klapperkop - Yesterday and Today (Pretoria, 1968). Publikasie no 1/Publication no 1, pp 95,95. ${ }^{63}$

2. Kmd W. Otto Die Spesiale Diensbataljon (1933-1973), met aanvullende bydraes deur brig J.N. Blatt, kol J. Ploeger en maj F.J. Jacobs (Pretoria, 1973). Publikasie no 2, pp 149.

3. Kol C.M. Bakkes Die Britse Deurbraak aan die Benede Tugela op Majubadag 1900 (Pretoria, 1972). Publikasie no 3, pp 92.

4. Maj F.J. Jacobs, It R.J. Bouch, S. du Preez, R. Cornwell, Suid-Afrikaanse Seinkorps, South African Corps of Signals (Pretoria, 1975). Publikasie no 4/Publication no 4, pp 107.

5. Capt/Kapt R.J. Bouch (ed)./red). Infantry in South Africallnfanterie in Suid-Afrika 1652-1976 (Pretoria, 1977). Publication no 5/ Publikasie no 5, pp 276.

6. Maj J.E. Rabie Generaal C.R. de Wet se krygsleiding by Sannaspos en Groenkop (Pretoria, 1980). Publikasie no 6/Publication no 6, pp 67.

7. Maj E.A. van Jaarsveld ea., Militêre Geneeskunde in Suid-Afrika (Pretoria, 1983). Publikasie no 7/Publication no 7, pp 119.

8. Kmdt C.J. Nöthling (red./ed.), Ultima Ratio

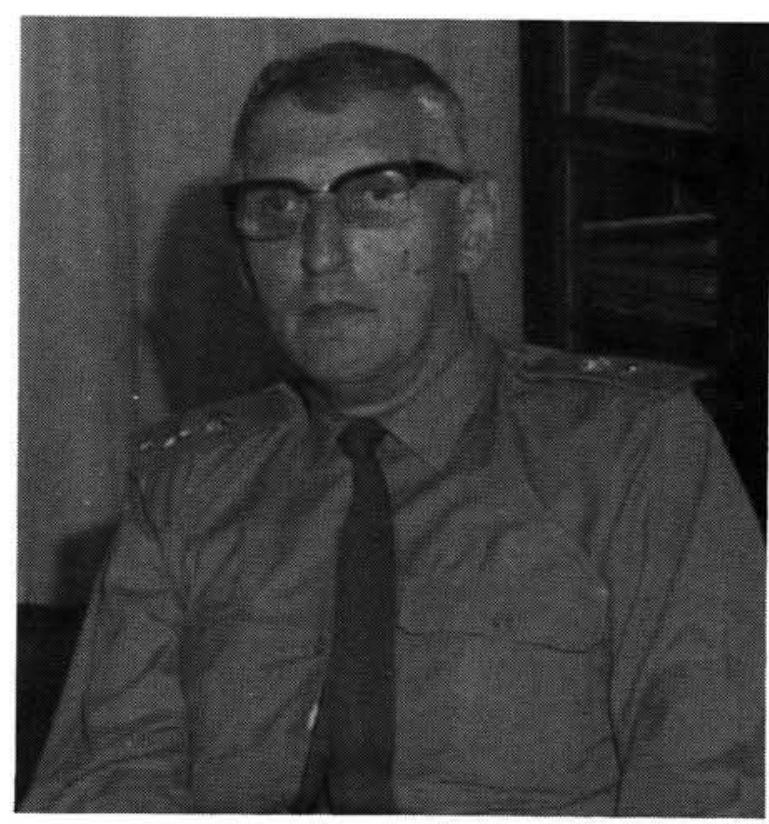

Kol (dr) (destyds kmdt) Jan Ploeger, die outeur van hierdie artikel (SAW Argief 700010230) 
Regu (The last argument of kings) (Artilleriegeskiedenis van Suid-Afrika) (Artillery History of South Africa) (Pretoria, 1987). Publikasie no. 8/Publication no 8, pp 432.

Al hierdie publikasies is, waar nodig van illustrasies en kaarte voorsien en beskik oor bruikbare registers. Terwyl hierdie werke deur personeellede opgestel en persklaar gemaak is, is met betrekking tot ander amptelike, departementele publikasies, hulp verleen. In dié verband word o.m. genoem Kenneth A. Maxwell, John M. Smith, Per aspera ad astra 1920-1970. SA Air Force Golden Jubilee Souvenir Book/SA Lugmag Goue Jubileumgedenkboek (Johannesburg, 1970) and Commodore J.C. Goosen, SM, South Africa's Navy The First Fifty Years (Cape Town, 1973), pp 228, en Wilhelm Grüther se vertaling, tw Ons Vloot Die eerste vyftig jaar (Kaapstad, 1973), pp 228. ${ }^{64}$

\section{Militêr-historiese publikasies van die Instituut vir Geskiedenisnavorsing van die Raad van Geesteswetenskaplike Navorsing (1972-1986). ${ }^{65}$}

Soos die Raad vir Geesteswetenskaplike Navorsing (RGN) reeds vroeër genoem is in verband met die verlening van geldelike hulp aan die Advieskomitee moet dit beklemtoon word dat dié organisasie ook navorsing in verband met militêre geskiedenis onderneem. Met dié doel voor oë is o.m. die Instituut vir Geskiedenisnavorsing (Institute for Historical Research) in die lewe geroep.

Onder leiding van kol (dr) C.M. Bakkes is in 1972 besluit om bronne-publikasies met ' $n$ militêr-historiese inslag deur personeellede van die Instituut persklaar en van geskiedkundige aantekeninge te laat voorsien. Van 1972-1986 het die volgende bronnepublikasies verskyn:

1. A.G. Oberholster (red.), Dagboek van H.C. Bredell 1900-1904, 1972.

2. J.P. Brits (ed.), Diary of a National Scout P.J. du Toit 1900-1902, 1974.

3. O.J.O. Ferreira (red.), Geschiedenis, werken en streven van S.P.E. Trichardt Luitenant Kolonel der vroegere Staatsartillerie Z.A.R. door hemzelve beschreven, 1975.

4. C.E. Eloff (red.), Oorlogsdagboekie van H.S. Oosterhagen Januarie-Junie 1902, 1976.

5. Thariza van Rensburg (red.), Oorlogsjoernaal van S.J. Burger 1899-1902, 1977.

6. O.J.O. Ferreira (red.), Krygsgevangenschap van L.C. Ruijssenaers 1899-1902, 1977.
7. A.G. Oberholster (red.), Oorlogsdagboek van Jan F.E. Celliers 1899-1902, 1978.

8. Thariza van Rensburg (ed.), Camp Diary of Henrietta E.A. Armstrong Experiences of a Boer nurse in the Irene Concentration Camp, 6 April-11 October 1901, 1980.

9. O.J.O. Ferreira (ed.), Memoirs of General Ben Bouwer as written by P.J. le Riche, 1980.

10. A.P. Smit en L. Mare (red.), Die beleg van Mafeking, 1985.

11. A. Wessels (ed.), Anglo-Boer War Diary of Herbert Gwynne Howell, 1986.

Uit hierdie titelvermeldings word dit duidelik dat die betrokke publikasies geheel of gedeeltelik betrekking op die jare van die Tweede AngloBoereoorlog het. Gen Ben Bouwer se militêre herinneringe loop deur tot 1914. Die herinneringe van die latere kol H.C. Bredell het hoofsaaklik met president S.J.P. Kruger se verblyf in Europa te doen. Die kampe was 'n uitvloeisel van die oorloggebeure, Jan F.E. Celliers se dagboek munt uit deur ' $n$ hoë graad van sensitiwiteit. Sy dagboek was o.m. sy toevlugsoord om geestelik staande te bly. ${ }^{66}$ Petrus Jacobus du Toit het uitgeroep:

"Oh, God of Gods, hast thou let us over to ourselves, hast thou forsaken thy children, is there no help, no remedy, no peace? If our case is a hopeless one, what can I do to stop it? All is a mystery, I shall act soon, yes this very day of tomorrow." ${ }^{\text {"67 }}$

So is, in sommige van hierdie oorlogsdagboeke, innerlike worstelinge van mense op die strydtoneel vertolk.

\section{Die Argief-Jaarboekreeks (1983)}

Reeds verskeie jare voordat die eerste deel van die amptelike Argief-Jaarboek vir Suid-Afrikaanse Geskiedenis/Archives Year Book for South African History in 1938 deur die argiewe van die Unie van Suid-Afrika uitgegee is, het die bekende historikus prof $d r$ J.L.M. Franken, van die Universiteit van Stellenbosch, reeds die wenslikheid van so ' $n$ amptelike publikasie bepleit. ${ }^{68}$ Die regering het fondse beskikbaar gestel en die destydse hoofargivaris van die Unie, mnr (later dr) C. Graham Botha, wat deur 'n redaksieraad bestaande uit assistent-hoofargivaris $\mathrm{dr}$ Coenraad Beyers, prof dr H.B. Thom en mnr P.J. Venter, MA (argivaris, sekretaris) bygestaan is, het in 1938 die reeds geruime tyd gekoesterde planne verwesenlik. 
In sy inleiding tot die eerste deel van die reeks het die hoofargivaris o.m. beklemtoon dat die jaarboek sou dien om argivale vraagstukke, sowel as die vrugte van nougesette wetenskaplike navorsing onder die aandag van belangstellendes te bring.

In die loop van die jare is meermale bewys dat die jaarboek reeks wat tot vandag toe verskyn, in ' $n$ behoefte voorsien het en nog by voortduring ' $n$ belangrike plek inneem. Uiteenlopende fasette van die resultate van geskiedkundige navorsing is en word nog steeds onder die aandag van die leserskring gebring.

Die militêr-historiese onderwerpe is nie verwaarloos nie. Volgens alfabeties geranskikte skrywersname is, in die registers, die volgende militêr-historiese en aanverwante studies genoem:

Bakkes, C.M. Die Militêre Situasie aan die Benede-Tugela op dié Vooraand van die Britse Deurbraak by Pietershoogte (26 Februarie 1900) (1967, deel 1).

Barnard, B.J. 'n Lewensbeskrywing van Majoor Henry Douglas Warden (1948, deel 1).

Barnard, C.J. Robert Jacob Gordon se Loopbaan aan die Kaap. (1950, deel 1)

Campbell, dr. W.B. The South African Frontier, 1865-1885. A study in Expansion.

Cilliers, J.H., Die Slag van Spioenkop (24 Jan 1900).

Coetzee, C. G., Die Kompanjie se besetting van Delagoabaai. (1948, deel 2).

Davey, A.M., The Siege of Pretoria, 1880-1881. (1956, deel 1).

De Villiers, C.J., Die Britse Vloot aan die Kaap, 1781-1806. (1969, deel 1).

De Villiers, J., Hottentotregimente aan die Kaap, 1781-1806. (1970, deel 2).

Grimsehl, H.W., Onluste in Modjadjiland, 1890-1894. (1955, deel 2).

Hatting, J.L., Die Irenekonsentrasiekamp. (1967, deel 1).

Mouton, dr. J.A., Genl Piet Joubert in die Geskiedenis van Transvaal. (1957, deel 1).

Nel H.F., Die Britse Verowering van die Kaap in 1795. (1972, deel 2).

Smith, K.W., The Campaigns against the Bapedi of Sekhukhune 1877-1879. (1967, deel 2).

Snyman, J.H., Rebelle-Verhoor in Kaapland gedurende die Tweede Vryheidsoorlog met Spesiale Verwysing na die Militêre Howe (1899-1902). (1962).

Snyman, dr J.H., Die Afrikaner in Kaapland, 1899-1902) (1979, deel 2)

Van Heerden, dr J.J., Die Kommandant-gene- raal in die Geskiedenis van die Suid-Afrikaanse Republiek. (1964, deel 2).

Van Jaarsveld, F.A. Die Veldkornet en sy aandeel in die opbou van die Suid-Afrikaanse Republiek tot 1870 (1950, deel 2).

Van Niekerk, M., Adolf Schiel en die Duitse Kommando. (1951, deel 2).

Van Wyk, A.J., Dinizulu en die Usoto-opstand van 1888. (1979, deel 1).

Van Zyl, dr M.C., Die uitbreiding van die Britse gesag oor die Natalse Noordgrensgebiede (1879-1897). (1966, deel 1).

Wales, J.M., The relationship between the Orange Free State and the Rolong of Thaba' Nchu during the Presidency of J.H. Brand, 1864-1888.(1986, deel 1). ${ }^{69}$

Die redaksie van die jaarboek berus by die Direkteur van Argiewe en die Argiefkommissie.

\section{Staatshistorici en hulle werksaamhede (1959-1987).}

In 1959 het die destydse Unieregering besluit om die pos van Staatshistorikus in die lewe te roep. In dié verband is dr Johan Hendrik Breytenbach benoem. Dr Breytenbach het sedert 1939 diens in onderskeie argiefbewaarplekke gedoen en hom sedert 1940 onafgebroke aan 'n diepgaande studie van die bronne oor die Tweede Anglo-Boereoorlog gewy. Voor sy aanstelling as Staatshistorikus het hy hierdie studie in sy vrye tyd op kantoor verrig, na sy benoeming in 1959 het hy hom voltyds aan dié taak gewy. Sy opdrag was en is om die militêre geskiedenis van die genoemde oorlog na te vors en om sy bevindings, met die oog op publikasie, te boekstaaf. ${ }^{70}$

Verskillende redes het, aldus dr Breytenbach in sy eerste deel, die regering van die Republiek laat besluit om die genoemde geskiedenis te laat beskryf en te publiseer.

In die eerste plek was dié oorlog die grootste en roemrykste kryg wat ooit in Suid-Afrika gevoer is. Dit het die inwoners van die twee republieke sowel as die Kaapkolonie en Natal geraak. Dit het manne soos generaals C.R. de Wet, L. Botha en J.H. de la Rey opgelewer wat, vanweë die rol wat hulle gespeel het, wêreldroem verwerf het. Die oorlog het, soos geen ander gebeurtenis nie, die belangstelling van die hele beskaafde wêreld op Suid-Afrika gevestig.

Ten spyte van hierdie kenmerke was dieselfde oorlog se geskiedenis in sy geheel nog nooit 
wetenskaplik beskryf nie, omdat -aldus dr Breytenbach-, die omvang van die bestaande bronnemateriaal wat oor die stryd bestaan, so groot is dat ' $n$ persoon -wat die bestudering daarvan nie as ' $n$ lewenstaak maak nie, dit nie kan voltooi nie. ${ }^{71}$

In die tweede plek gaan die werke waarin die oorlog wel volledig behandel is, aan ernstige gebreke mank. In dié verband het dr Breytenbach verklaar:

"In die geval van die grootste massa daarvan is waarheid en verdigsel so met elkaar vermeng as gevolg van die sentimente van die skrywers dat hulle nie 'n getroue beeld gee van wat werklik gebeur het nie. Die paar uitsonderinge word weer daardeur gekenmerk dat hulle almal op onvolledige en oorhaastige navorsing berus" 72

In dié geval is tereg aangevoer dat slegs enkele skrywers kennis van die groot massa bronne in die Suid-Afrikaanse argiefbewaarplekke geneem het en dat hulle werke nooit gepubliseer is nie. Verder is aangevoer dat dié werke nie wetenskaplik verantwoord was nie of uit druk is.

Op grond van hierdie omstandighede is daar, van regeringsweë, tot die volgende gevolgtrekking gekom:

"Daar bestaan dus 'n ernstige behoefte aan 'n omvattende werk waarin die verloop van die oorlog aan die hand van alle beskikbare bronne binne in en buite Suid-Afrika beskryf word, en waarin alle feite wat genoem word behoorlik in voetnote verantwoord word. ${ }^{\text {"73 }}$

Dr Breytenbach het, onder toesig van 'n komitee, wat oorspronklik deur die regering benoem was om toesig oor die werk te hou, met die uitvoering van sy omvattende taak egin. Die eerste komitee het uit prof dr A.N. Pelzer, prof dr F.J. du Toit Spies en dr T.S. van Rooyen, almal van die Departement Geskiedenis van die Universiteit van Pretoria, bestaan. ${ }^{74}$

In die jare 1969-1987 het die volgende dele van die reeks Die geskiedenis van die Tweede Vryheidsoorlog in Suid-Afrika, 1899-1902, die lig gesien:

1969 - deel 1 - Die Boere-offensief Oktober -

November 1899 (pp. 508, met illustrasies, kaarte, register). ${ }^{75}$ Dié amptelike publikasie het, soos dié wat later verskyn het, op las van die Minister van Nasionale Opvoeding en onder toesig van die Departement Geskiedenis, Universiteit van Pretoria, die lig gesien.

1971 - deel 2 - Die Eerste Britse offensief November - Desember 1899 (pp 513, soos bo) $)^{76}$

1973 - deel 3 - Die stryd in Natal Januarie Februarie 1900. (pp 594, soos bo) ${ }^{77}$

1977 - deel 4 - Die Boereterugtog uit Kaapland (pp 513, soos bo) ${ }^{78}$

1983 - deel 5 - Die Britse opmars tot in Pretoria (pp 587, soos bo) $)^{79}$

Op 31 Oktober 1982 het Staatshistorkus dr J.H. Breytenbach die ouderdomsgrens bereik, maar besluit om na sy aftrede, met sy amptelike werksaamhede voort te gaan. ${ }^{80}$

Dr J.A. Mouton het, soos, dr J.H. Breytenbach, 'n jarelange verbintenis met die Staatsargief gehad toe hy, na hom, as Staatshistorikus aangestel is. Sy amptelike taak was om die ontstaan en ontwikkeling van die konsentrasie- of burgerkampstelsel na te vors en te boekstaaf. Dr Mouton was gedeeltelik met die uitvoering van sy taak gereed toe die dood hom weggeruk het.

Hy is in 1973 deur die skrywer van hierdie bydrae, na sy aftrede as Senior Stafoffisier Argief en Navorsing, Suid-Afrikaanse Weermag, in 'n tydelike hoedanigheid opgevolg. Na ongeveer sewe jaar verdere navorsing is ' $n$ aantal hoofstukke oor die burgerlike aspekte van die oorlog op skrif gestel. Daar is besluit om dié hoofstukke, na rekenaarverwerking te publiseer. Dié werk is nog aan die gang. Verder is geskiedenisse van elke afsonderlike kamp vir Blankes en 'n samevattende oorsig oor die kampe vir Swartes opgestel. Op dié wyse is ruim 100 hoofstukke in handskrif gereed gemaak. Die ondergetekende het in 1983 weliswaar afgetree, maar onderneem om die projek te voltooi. In Februarie 1987 het hy sy diens beëindig. In die hoofstukke is o.m. op die lewenswyse, die ervaringe, die moraal en die problematiek van mense in onvryheid gekonsentreer. ${ }^{81}$

\section{SLOTBESKOUING}

In hierdie bydrae het die skrywer hom daarop toegespits om, binne die grense van sy vermoëns en vir hom bekende gegewens ' $n$ oorsig te gee van Suid-Afrikaanse staats- en staatsondersteunde militêre geskiedskrywing (1924-1987).

Hierdie bydrae is ongetwyfeld, maar onopsetlik, nie volledig nie. Nieteenstaande hierdie tekort- 
koming sal die leser tog 'n indruk verkry van die vordering wat daar in die loop van die jare gemaak is. Dié vordering stem tot dankbaarheid.

\section{PRETORIA, JANUARIE-FEBRUARIE 1988}

\section{Aantekeninge}

1. Om F.A. van Jaarsveld en J.I. Rademeyer, Teorie en metodiek vir geskiedenisonderrig (Johannesburg, 1960), pp 15-65 (verspreide bladsye).

2. J. Huizinga, De wetenschap der geskiedenis (Haarlem 1937), pp 119-121. Die skrywer verklaar op pp 120 dat die krygsgeskiedenis, as 'n onderdeel van die kultuur- of tegniese geskiedenis, 'n selfstandige, belangrike plek binne dié raamwerk behou wat die algemene begrip geskiedenis omvat.

3. E. Creasy, The fifteen decisive battles of the world; From Marathon to Waterloo (London, 1887), $\mathrm{px}$.

4. Alfred von Müller, Der Krieg in Süd-Afrika 1899/1900 und seine Vorgeschichte (Berlin, 1900), pp 1-46.

5. H. Amersfoort, P.H. Kamphuis (ed.), Je Maintiendrai A concise history of the Dutch Army (The Hague, 1985), pp 7.

6. Ibid., p 7 .

7. Voor in die laasgenoemde publikasie is ' $n$ oorsig van dr C. se boeke en tydskrifartikels (1943-1963) opgeneem. Bladsynommers ontbreek.

8. P. Warwick, S.B. Spies, The South African War The Anglo-Boer War 1899-1902 (London, 1890), pp 6. Kursivering deur skrywer.

9. N. Hofmeyr, Zes maanden bij de Commando's ('sGravenhage, 1903). Hy is deur die Uitvoerende Raad van die Zuid-Afrikaansche Republiek as "Geschiedschrijver van den Oorlog" aangestel.

10. Ibid., pp 5.

11. W.F. Andriessen, Gedenkboek van den Oorlog in Zuid-Afrika (Amsterdam - Kaapstad, 1904) pp ix-x.

12. Ibid., $\mathrm{pp} \mathrm{x}$.

13. W. Vallentin, Der Burenkrieg (Wald - Solingen, Leipsig, 1902), deel I, pp v.

14. Ibid., pp vi.

15. L.S. Amery, The Times History of The War in South Africa 1899-1900 (London, 1900), pp iii e.v.

16. Ibid., $\mathrm{pp} v-\mathrm{vi}$.

17. Ibid., pp vi.

18. Ibid., deel 2 (1902), pp ve.v.

19. Die Kämpfe der deutschen Truppen in Südwestafrika (Berlin, 1906) Erstes Heft, Vorwork.

20. Official Year Book of the Union of South Africa and of Basutoland, Bechuanaland Protectorate, and Swaziland (Pretoria, 1921), pp 408 e.v.

21. C.F.J. Muller (red), Vyfhonderd Jaar Suid-Afrikaanse Geskiedenis (Pretoria, Kaapstad, 1968), pp 352 e.v.

22. Official Year Book... no 4 (Pretoria, 1921), pp 411.

23. The Union of South Africa and the Great War 1914-1918 (Pretoria, 1924) vermelding op die agterkant van die titelblad.

24. Piet van der Byl, From playgrounds to battlefields (Cape Town, 1971), pp 145-146. Die skrywer kon tydens sy dienstydperk in die SAW vasstel dat maj $\mathrm{L}$. die outeur was.

25. The Union of South Africa ..., pp 4

26. Ibid., pp 3.

27. The Official History is soos volg ingedeel: Die veldtog in DSWA en die rebellie, pp 10-60; die veldtog in DOA, pp 63-93; die SA Infanteriebrigade in Frankryk, pp 100-182; die SA Swaar Artillerie, pp 185-189; die SA Seinkompanie, pp 189-200 die
SA Mediese diens, pp 200-205; die Spoorwegk̄ompanies edm, pp 207-208; die administrasie, pp 211-224. Victoria Crosses deur Suid-Afrikaners verwerf, pp 225-228. Suid-Afrikaanse gesneuweldes en ander noodlottige ongevalle, pp 229-230.

28. J.H.V. Crowe, General Smuts' Campaign in East Africa (London, 1918), pp v-vi.

29. J.J. Collyer, The Campaign in German South West Africa 1914-1915 (Pretoria, 1937), preface.

30. Ibid.

31. Ibid., pp 165-173.

32. Ibid., pp 173.

33. Die uitgawe van 1937 het 180 en die vertaling van 1939196 bladsye beslaan. Albei is deur die Staatsdrukker, Pretoria, as amptelike publikasies gedruk.

34. Engelse uitgawe: Rooi omslag, 299 bladsye teks en register, 21 meerkleurige militêre kaarte.

Afrikaanse uitgawe: Groen omslag, 308 bladsye teks en register, 21 meerkleurige militêre kaarte.

35. J.J. Collyer, Die Suid-Afrikaners met Generaal Smuts in Duits Oos-Afrika 1916 (Pretoria, 1939), pp xi.

36. Ibid., pp xii-xiii. In dié verband het die skrywer na dié verklaring van die Unie se Minister van Verdediging op 13 Oktober 1937 verwys waarin o.m. gesê is dat die Departement van Verdediging se militêre beleid op dié veronderstelling gegrond was dat die Unie ' $n$ lid van die Britse gemenebes sou bly ( $p$ xiii).

37. Ibid., $\mathrm{pp} \times \mathrm{x}$.

38. Ibid., $\mathrm{pp}$ ix $-\mathrm{x}$.

39. Ibid., pp 268-298 (Afr uitgawe), pp 260-289 (Eng uitgawe).

40. London, 1941, pp 603 (teks register), 67 kaarte.

41. Ibid., pp xix.

42. Ad Destinatum Gedenkboek van die Universiteit van Pretoria (Johannesburg, 1960), pp 112, besonderhede aangaande J.A.I. Agar-Hamilton. Die skrywer het sy werk van 1941-1946 waargeneem (tydelik).

43. J.A.I. Agar-Hamilton, L.C.F. Turner, The Sidi Rezeg Battles 1941 (Cape Town, London, N. York 1957), pp vi. Neil Orpen, East African and Abyssinian Campaigns (Cape Town, Johannesburg, 1968), p iii. In 1943 het die UVM Historiese Advieskomitee tot stand gekom. In 1945 is dié benaming verander na Oorlogsgeskiedenis Advieskomitee. Dié komitee is op 31 Mei 1979 ontbind Argiefnuus, Julie 1983, " 'n Kort geskiedenis van die Militêre Informasieburo", pp 41.

44. J.A.I. Agar-Hamilton, L.C.F. Turner, Crisis in the Desert May-July 1942 (Cape Town, London, N. York, 1952), $\mathrm{px}$.

45. Ibid., The Sidi Rezeg Battles 1941, p 6. Ivm die lewe en werk van hoofargivaris dr Coenraad Beyers, S.A. Argiefblad - SA Archives Journal, 1976, pp 33-37, W.B. van der Vyver, "Dr Coenraad Beyers".

46. Kyk die voorwoord van elkeen van die publikasies.

47. J.A.I. Agar-Hamilton, L.C.F. Turner, Crisis in the Desert May-July 1942, p vii e.v. Oplaag 4000 , pp 368.

48. J.A.I. Agar-Hamilton. L.C.F. Turner, The Sidi Rezeg Battles 1941, p 505

49. L.C.F. Turner, H.R. Gordon-Cumming, J.E. Betzler, War in the Southern Oceans 1939-1945, p 288.

50. Argiefnuus, Oktober 1961, E.J. Smith, "Die Unie-Oorlogsgeskiedenis", p 20, ev Ibid., Julie 1983, pp
38-46.

51. C. Birkby, Springbok Victory (Johannesburg, 1941?) Author's Note, Cape Town, 1 September 1941. Die skrywer was SAPA se eerste oorlogskorrespondent met die troepe in Oos-Afrika.

52. Harry Klein, Springboks in Armour (Cape Town, Johannesburg, n.d.), pp vii, vi.

53. Neil Orpen, East African and Abyssinian Campaigns, 
p iii, James Ambrose Brown, A Gathering of Eagles, p vi.

54. Kyk aantekening 53, onder N. Orpen, pp iii-iv. Die gewysigde samestelling van die komitee is in die daaropvolgende dele van die reeks vermeld.

55. James Ambrose Brown, A Gathering of Eagles, $\mathrm{p}$ vi.

56. Neil Orpen, War in the Desert, p v.

57. Katalogus/Catalogue Lt Genl Brink - Uitstalling (Lt Gen Brink Exhibition, 1971 (MHAD/NGAS, gestensil, p 44).

58. Met kaarte en afbeeldings, $p$ 346. Die Departement van Onderwys, Kuns en Wetenskap het ' $n$ deel van die navorsing gesubsidieer.

59. In 1970 het verskyn: Neil Orpen. The Cape Town Highlanders (Cape Town, 1970), p 396.

60. James Ambrose Brown, The Return (Cape Town, Johannesburg, 1971, p 191

61. Argiefnuus, Julie 1983, p 38 e.v

62. In hierdie bydrae word nie op Militaria en ander soortgelyke tydskrifte ingegaan nie.

63. Hierdie publikasie het sy ontstaan te danke aan die amptelike besluit om die Forte Klapperkop en Schanskop te restoureer. Oplaag: 2500 eks. (Afr.), 2500 eks. (Eng.).

64. Ivm die aandeel van kommodoor J.C. Goosen, S.M. Ivm die totstandkoming van die publikasie is vermeld dat die werk deur die Suid-Afrikaanse MarineKorporasie Bpk/South African Marine Corporation Ltd, geborg is. Die geheel is in oorleg met die SA Vlootowerhede onder leiding van Kommodoor J.C. Goosen, SM, saamgestel.

65. Die einddatum (1986) is gebaseer op ' $n$ lys van titels verstrek deur mev A. van Zyl, RGN-publikasies.

66. A.G. Oberholster, M.A. (red), Oorlogsdagboek van Jan F.E. Celliers 1899-1902 (Pretoria, 1978), p 7.

67. J.P. Brits, M.A. (ed), Diary of a National Scout P.J. du Toit 1900-1902 (Pretoria, 1974), p 33.

68. Argief-Jaarboek vir Suid-Afrikaanse Geskiedenis/ Archives Year Book for South African History (Kaapstad/Cape Town, 1938) jg. 1, deel 1; volume 1, part 1. Preface.

69. Ibid., jg. 43, deel 1 (Pretoria, 1980), pp 377-384.

70. Argiefnuus, jg. xxv, no 6, Des 1982, p 21 e.v.; Ibid, jg xxi, no 6, Okt 1978. p 10 e.v. J.H. Breytenbach, Die geskiedenis van die Tweede Vryheidsoorlog in SuidAfrika, 1899-1902 (Pretoria, 1969), deel I, voorwoord $1 \mathrm{p} \mathrm{ix}$.

71. Kyk aantekening 70, laasgenoemde bron, voorwoord, $\mathrm{p}$ ix

72. Ibid.

73. Ibid

74. Ibid., $\mathrm{px}$

L.W. Dieselfde onderwerp is, onder die titel "Twintigste eeuwse militaire geschiedschrijving in Zuid-Afrika (dele 1 en 2), gedeeltelik in Zuid-Afrika (Amsterdam), jg.65. 6,7 en 8,1988 , behandel.

* Kol (dr) Jan Ploeger, SSO Argief en Navorsing, SAW, 1964-73, Staatshistorikus, RSA, 1973-1983. 